\title{
13 \\ Stormwater Quality Descriptions using the Three Parameter Lognormal Distribution
}

\author{
Alexander Maestre, Robert Pitt, S. Rocky Durrans and Subhabrata \\ Chakraborti
}

The cumulative probability distribution used to describe the variability of stormwater pollutant concentrations has been a matter of interest in recent years. Many predictive models attempt to estimate appropriate stormwater constituent concentrations based on land use and the amount of impervious area. The most important study that characterized stormwater was the Nationwide Urban Runoff Program (NURP) (EPA 1983). NURP was conducted throughout the U.S. and included about 2300 events from 1978 through 1982. One of the conclusions of the final NURP report was that the event mean concentrations (EMCs) of stormwater constituents were described by lognormal distributions. This finding has been re-evaluated recently, with the conclusion that not all stormwater constituents are adequately described by lognormal distributions (Van Buren, 1997; Beherra, 2000).

Stormwater managers have generally accepted the assumption of lognormality of stormwater constituent concentrations between the 5th and 95th percentiles. Based on this assumption, it is common to use the logtransformed EMC values to evaluate differences between land use categories and other characteristics. Statistical inference methods, like estimation and test of hypothesis, and analysis of variance (ANOVA) require statistical information about the distribution of the EMC to evaluate these differences. The use of log-transformed data usually includes the location and scale parameter, but a lower bound parameter is usually neglected. In this chapter, a large database, the National Stormwater Quality Database v.1.1 (NSQD) (Pitt, et al. 2003), will be used to evaluate a three-parameter lognormal distribution for stormwater constituent concentrations for different land uses. The NSQD

Maestre, A., R.E. Pitt, S. Durrans and S. Chakraborti. 2005. "Stormwater Quality Descriptions using the Three

Parameter Lognormal Distribution." Journal of Water Management Modeling R223-13. doi:

10.14796/JWMM.R223-13.

(C) CHI 2005 www.chijournal.org ISSN: 2292-6062 (Formerly in Effective Modeling of Urban Water Systems. ISBN: 0-9736716-0-2) 
is a compilation of the phase 1 data from the stormwater permit program. This chapter will also evaluate this national data for the presence of unusual elevated values and their effect on the goodness of fit for the three parameter lognormal distribution.

\subsection{Introduction}

The National Stormwater Quality Database v. 1.1 (NSQD) contains water quality characteristics from the monitoring required by the NPDES Phase 1 stormwater permit applications and subsequent permits, during the period of 1992 to 2002. This database contains about 3770 events from 256 sites in 66 communities from throughout the U.S. For each site, much additional data, including the percentage of each land use in the catchment, the total area, the percentage of imperviousness, the geographical location and the season, has been included in the database. Information about the characteristics of each event is also included. Total precipitation, precipitation intensity, total runoff and antecedent dry period are also included, if collected. The database only contain data collected at the outfall, in-stream samples were not included in the database. Water quality characteristics where divided in four main groups: Common parameters, nutrients, metals and others (ie. pesticides and organic compounds). Much time and effort was spent in reviewing these data for $\mathrm{QA} / \mathrm{QC}$ problems and correcting the information.

The Nationwide Urban Runoff Program (NURP) evaluated the characteristics of stormwater discharges at 81 outfalls in 28 communities throughout the U.S. (EPA, 1983). One of the conclusions was that stormwater constituent concentrations could be described using a lognormal distribution. Recently, Van Buren (1997) found that stormwater concentrations were described using a lognormal distribution for almost all constituents, with the exception of dissolved constituents that were better described with a normal distribution. Beherra (2000) also found that some stormwater constituent concentrations were better described using a lognormal distribution, while others were better described with gamma or exponential distributions. The constituents that were best described with a gamma distribution were: total solids, total Kjeldahl nitrogen (TKN), total phosphorous, chemical oxygen demand (COD), barium and copper. The constituents that were best described with an exponential distribution were: suspended solids, nitrates and aluminum. In both of these studies, fewer than 50 samples (collected at the same site) were available for evaluation. 
During the research reported in this chapter, statistical tests were used to evaluate the log-normality of a selection of the constituents in the NSQD database. Statistical descriptions were obtained of each set of data including box and probability plots for each land use category and for the pooled dataset. It was found in almost all cases that the log-transformed data followed a straight line between the 5th and 95th percentile, as illustrated in Figure 13.1 for total dissolved solids (TDS) in residential areas.

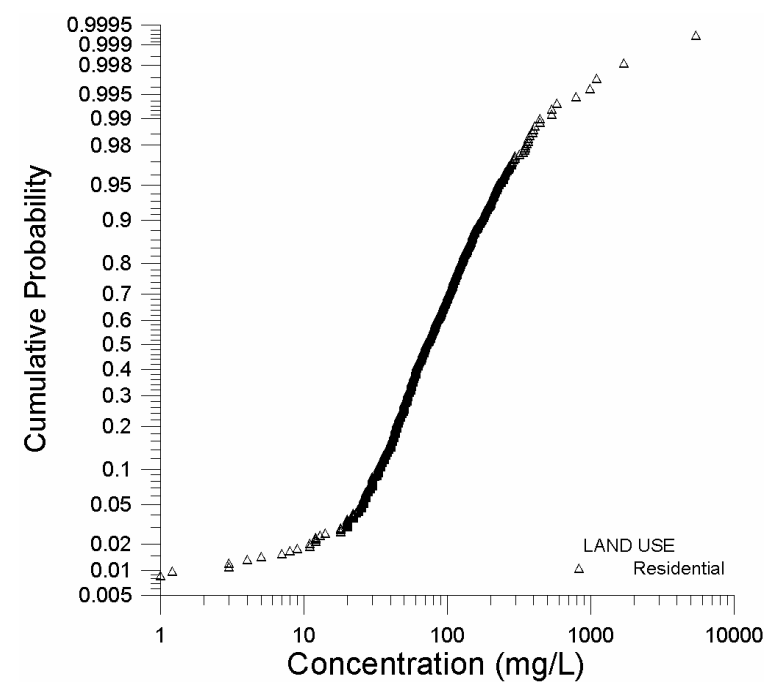

Figure 13.1 Probability plot of total dissolved solids in residential land uses.

For many statistical tests focusing on the central tendency (such as for determining the average concentration that is used for mass balance calculations), this may be a suitable fit. As an example, WinSLAMM, the Source Loading and Management Model (Pitt 1986; Pitt and Voorhees 1995), uses a Monte Carlo component to describe the likely variability of stormwater source flow pollutant concentrations using either lognormal or normal probability distributions for each constituent. However, if the extreme values are of importance (such as when dealing with the influence of many nondetectable values on the predicted concentrations, or determining the frequency of observations exceeding a numerical standard), a better description of the extreme values may be valuable.

The NSQD underwent an extensive data evaluation process, including multiple comparisons of the all data value in the database to original 
documents. In some cases, data was available from the local agency in electronic form. These spreadsheets were reformatted to be consistent to the NSQD format. However, it was found that all of the submitted electronic data needed to be verified against original data sheets and reports. When reviewing the NSQD, it was assumed that some of the events in the upper and lower tails of the distributions were caused by errors, most likely due to faulty transcription of the data (such as mislabeling the units for heavy metals or nutrients as $\mathrm{mg} / \mathrm{L}$ instead of $\mu \mathrm{g} / \mathrm{L}$, for example). Unusual values were verified with the original reports and datasets. While some values (less than $5 \%$ of the complete dataset) were found to be in error and were corrected, most of the suspected values were found to be stormwater observations. Besides the targeted extreme values, all reported values were also examined in relationship to other related constituents (COD vs. BOD; total metal concentrations vs. dissolved metal concentrations; TKN vs. $\mathrm{NH}_{3}$; TDS vs. specific conductivity; SS vs. turbidity; etc) and unusual behavior was further checked and corrected, as necessary. In some cases, unusual values could not be verified and were therefore eliminated from the dataset, although this was very unusual.

After the extensive QA/QC activities and corrections were made to the NSQD, the next step was to conduct a sensitivity analysis to determine the effects of the remaining unusual high and low values on the probability distribution parameters.

\subsection{The Effects of Unusually High and Low Values on Probability Distribution Parameters}

For this evaluation, 10,000 sets of 200 samples each were randomly generated following a lognormal distribution $(1,1)$, but having differing amounts of extreme values in each data set. For each set, the mean, variance and coefficient of variation were calculated. Two main factors were analyzed using these data: the extreme value factor and percentage of extreme values in each sample. The following percentages of extreme values were selected for evaluation: $0.5,1,5,10,25$ and $50 \%$. For each percentage of extreme values, the following factors were analyzed: $0.001,0.01,0.1,10,100,1.000,10,000$, 100,000 and $1,000,000$. For example $(5 \%, 100)$ indicates that in each set, $5 \%$ of the data were increased by a factor of 100 . The coefficient of variation was then calculated for each set of data. The medians of the coefficients of 
variation for the 10,000 runs are shown in Figure 13.2 for each level of extreme values.

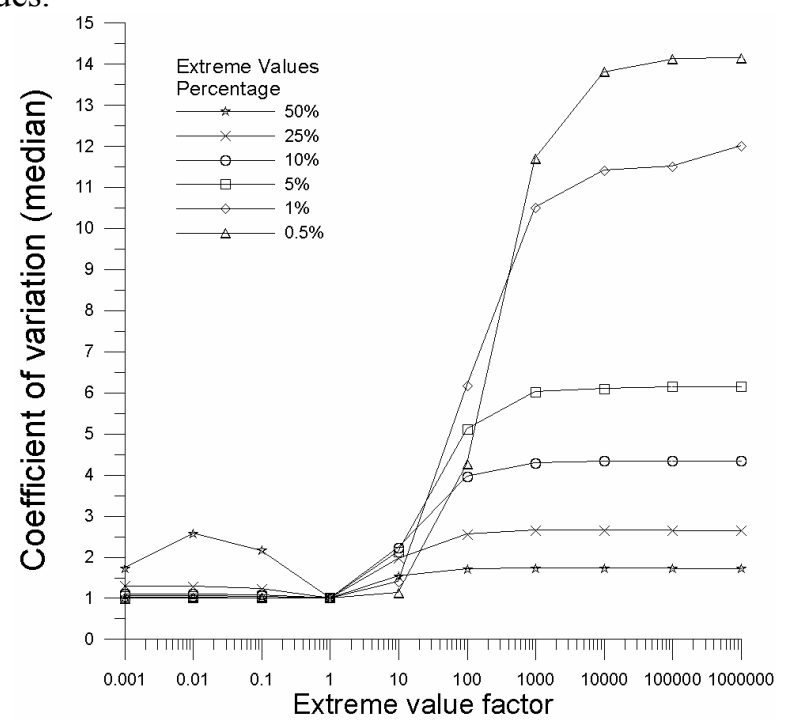

Figure 13.2 Effect of unusual values on the coefficient of variation (based on LN $(1,1)$.

For a lognormal distribution $(1,1)$ the coefficient of variation is one. Figure 13.2 shows how this original value is changed for different amounts of extreme values in the data sets, and for different factors in these extreme values. The horizontal axis represents the factor used in the extreme values. As an example, many of the incorrect extreme values observed in the NSQD for heavy metals were because the units were originally incorrectly reported as $\mathrm{mg} / \mathrm{L}$ in the submitted information, while the correct units were actually $\mu \mathrm{g} / \mathrm{L}$. This would be an extreme value factor of 1,000. Extreme value factors of 10 were also fairly common and were associated with simple misplacements of decimal points in the data.

This figure shows that for small error factors $(0.1,0.01$ and 0.001$)$ there is not a large effect in the coefficient of variation for percentages smaller than $10 \%$. For larger percentages the effect in the coefficient of variation is important. When $50 \%$ of the data are affected by an error factor of 0.01 , the coefficient of variation was increased by almost three times.

High extreme value factors can have an important effect on the coefficient of variation. When $10 \%$ of the data were increased by a factor of 10 , the 
coefficient of variation was increased almost three times. Notice that affecting $10 \%$ of the data by a factor of 10 have almost the same effect as affecting $50 \%$ of the data by a factor of a hundredth. This effect is reduced when the percentage of elevated values in the dataset is smaller than $10 \%$.

For factors larger than one hundred, the effect on the coefficient of variation is much greater. Very low percentages of elevated values can increase the coefficient of variation by up to 15 times. For example, when only $0.5 \%$ of the sample is affected by a factor of a thousand, the coefficient of variation increases almost 12 times more than the correct value. As noted earlier this is important because it is not unusual to find reported values affected by a factor larger than a hundred (See Figure 13.1). Some of these values can be due to incorrect reporting units, but in many cases they were considered as valid observations because they were supported by similarly high values of other closely related constituents. For factors greater than $10^{4}$ the multiplying value of the coefficient of variation remains stable at the maximum value obtained.

The above analyses indicate that in lognormal distributions, the presence of just a few unusual elevated values is important and can dramatically affect the reported coefficient of variation for the distribution of concentration. This observation is critical in the relatively common case where one or a very few observations are affected by a factor larger than a hundred. In the other extreme, factors smaller than one do not have a large impact on the reported coefficient of variation, except when the percentage of extreme values is greater than $50 \%$ (obviously, there are many other problems with that data set too).

The effect of extreme values on the mean and standard deviation was also analyzed. Figure 13.3 shows the effect of the extreme values on calculated standard deviation.

For large extreme value factors (larger than one) the standard deviation increases as the percentage of extreme values increases. For small extreme value factors, percentages smaller than $25 \%$ do not have an important effect on the standard deviation. For a specific extreme value factor, changing the extreme value percentages from $0.5 \%$ to $50 \%$ increases the standard deviation close to 10 times.

The effect of the presence of extreme value on the distribution mean is shown in Figure 13.4. For small extreme value factors, the mean is reduced almost $80 \%$ when the extreme value percentage is close to $50 \%$. This is expected because in a lognormal $(1,1)$ most of the values are located in the lower tail of the distribution. For extreme value occurrences less than $25 \%$, the mean value is reduced by less than $20 \%$. 


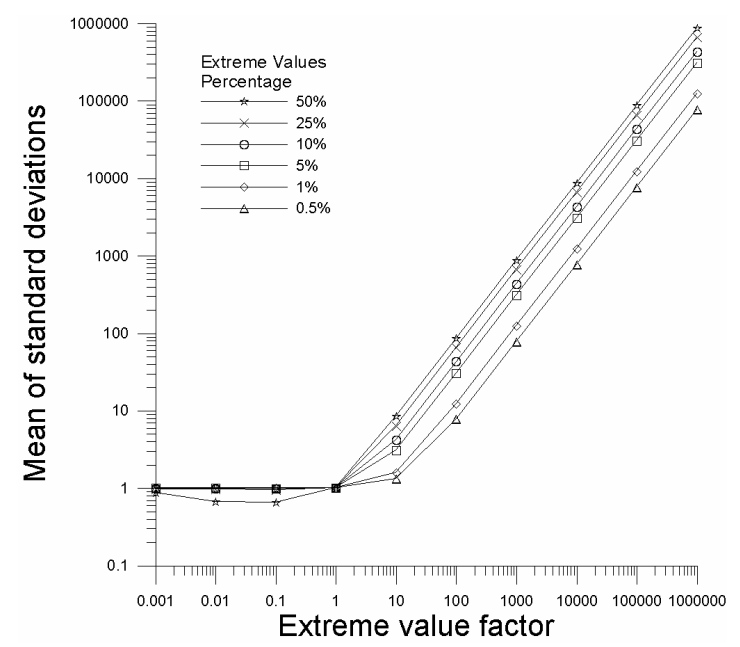

Figure 13.3 Effect of unusual values on the standard deviation (based on $\operatorname{LN}(1,1)$.

Large extreme values factor have much larger effects on the distribution means. As the extreme value percentage increases, the calculated means also increase. If $0.5 \%$ of the values are affected by a factor of a hundred, the mean value is doubled. If $50 \%$ of the values are affected by the same factor, the mean values are increased by almost 50 times. For factors larger than a thousand, increasing the percentages of extreme values from $0.5 \%$ to $50 \%$ increases the mean values by up to two orders of magnitude.

These evaluations are important because it points out that for a lognormal distribution, the effects of few elevated values in the upper tail have much greater effect on common statistics than unusual values in the lower tail. Many stormwater researchers have focused on the lower tail, especially when determining how to handle the detection limits and unreported data. Stormwater constituents usually have unusual values in both tails of the probability distribution. It is a common to delete elevated values from the observations assuming they are expendable "outliers". This practice is not recommended unless there is sufficient evidence that the observed values are a mistake. Actual elevated values can have a large effect on the calculated distribution parameters. If these are arbitrarily removed, the data analyses will likely be flawed. 


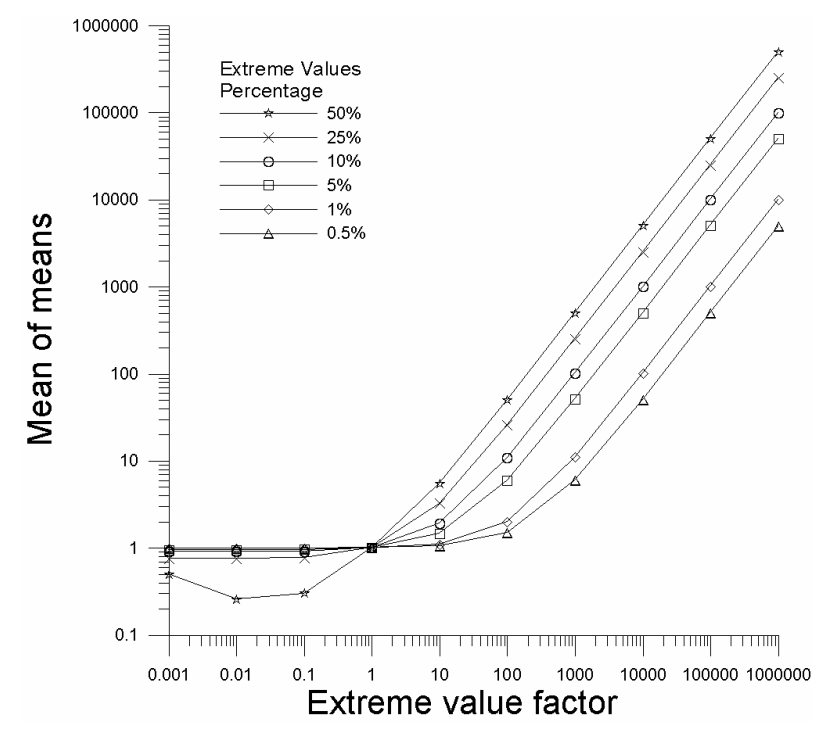

Figure 13.4 Effect of unusual values on the mean (based on $\operatorname{LN}(1,1)$.

\subsection{Analysis of Lognormality of Stormwater Constituents}

The goodness of fit of twenty-nine stormwater constituent probability distributions was evaluated using the Kolmogorov-Smirnov test. Figure 13.5 shows how the test accepts or rejects the null hypothesis that the empirical and the estimated distributions are the same. If the null hypothesis is valid, then the constituent can be adequately represented by the lognormal distribution. The observations are sorted and a probability is assigned by its rank. The distribution generated by this ranking is known as the empirical distribution. The estimated distribution function is also compared on the same plot. The estimated distribution function is calculated with the mean and standard deviation of the original data. If the distance between the empirical and the estimated distributions is higher than a critical value $\mathrm{d}_{\alpha}$ or $\mathrm{D}_{\max }$, the hypothesis of lognormality is rejected. Notice in Figure 13.5 that the horizontal axis has a logarithmic scale. 


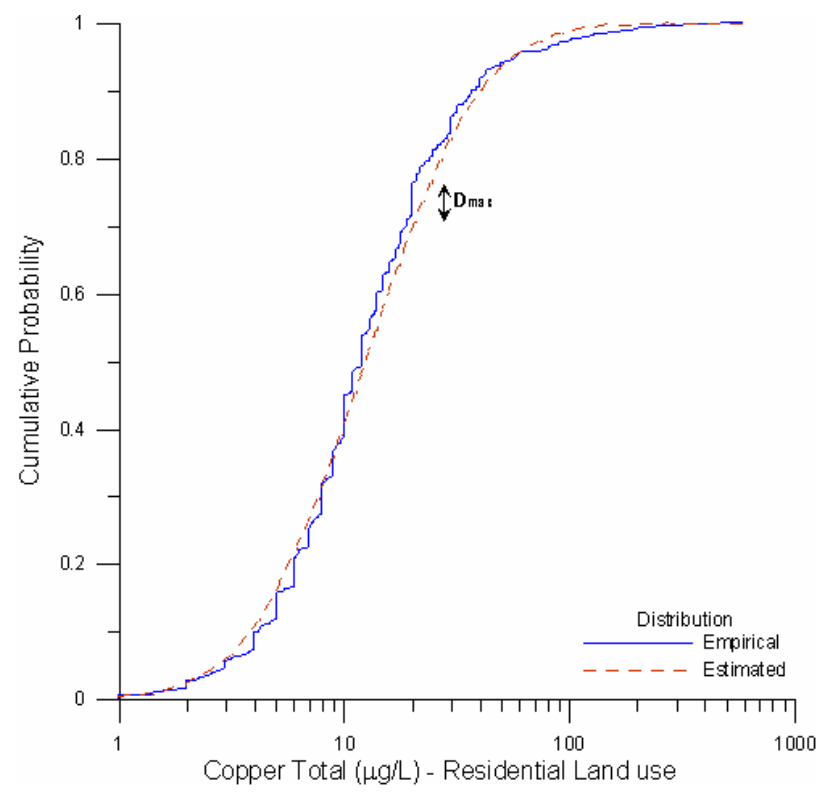

Figure 13.5 Cumulative and empirical probability distributions of total copper for residential land use data. Goodness of fit test, KolmogorovSmimov).

There are many options to assign the probability based on the ranks. Most methods assign the probability as a percentage of the total range. The probability of the observation is calculated as its rank divided by the number of observations. Kottegoda (1998) suggested that for extreme events analysis the plotting position can be calculated as:

$$
p=\frac{i-0.5}{n}
$$

where:

$$
\begin{aligned}
p & =\text { cumulative probability of the observation, } \\
i & =\text { rank of the observation and } \\
n & =\text { total number of observations. }
\end{aligned}
$$

We used this plotting position for these analyses because it does not restrict the probability of the largest observation to be one. 
In the Kolmogorov-Smirnov test, the null hypothesis is that the observed data follow a lognormal distribution. If the sample size is small, and the distance between the empirical and the observed distributions is smaller than the critical value $D_{\max }$, the test is interpreted as "there is not enough evidence to reject the hypothesis that the distribution is lognormal." In most cases, the NSQD contains enough samples to be able to accept or reject the null hypothesis with acceptable levels of confidence and power.

The NSQD contains many factors for each sampled event that likely affect the observed concentrations. These include such factors as seasons, geographical zones, rain intensities, etc. These factors may affect the shape of the probability distribution. As more data become available, the critical value $\mathrm{D}_{\max }$ is reduced in the test. There will always be a specific number of samples that will lead to rejection of the null hypothesis because the maximum distance between the empirical and estimated probability distributions became larger than the critical value $\mathrm{D}_{\max }$. The only way to evaluate the required number of samples in each category is using the power of the test. Power is the probability that the test statistic will lead to a rejection of the null hypothesis (Gibbons and Chakraborti, 2003).

Masey (1950) states that the power of the Kolmogorov-Smirnov Test can be written as:

$$
\text { power }=1-\operatorname{Pr}\left(\frac{-d_{\alpha} \pm \Delta \sqrt{n}}{\sqrt{F_{1}\left(x_{0}\right)\left(1-F_{1}\left(x_{0}\right)\right)}}<\frac{\left\{S_{n}\left(x_{0}\right)-F_{1}\left(x_{0}\right)\right\} \sqrt{n}}{\sqrt{F_{1}\left(x_{0}\right)\left(1-F_{1}\left(x_{0}\right)\right)}}<\frac{d_{\alpha} \pm \Delta \sqrt{n}}{\sqrt{F_{1}\left(x_{0}\right)\left(1-F_{1}\left(x_{0}\right)\right)}}\right)
$$

where:

$$
\begin{aligned}
d_{\alpha}= & D_{\max }: \text { critical distance at the level of significance } \\
& \alpha \text { (confidence of the test), } \\
S_{n}= & \text { Cumulative empirical probability distribution, } \\
F_{1}= & \text { Cumulative alternative probability distribution, } \\
\Delta= & \text { maximum absolute difference between the } \\
& \text { cumulative estimated probability distribution and } \\
& \text { the alternative cumulative probability distribution. }
\end{aligned}
$$

Massey (1951) also found that for large sample sizes, the power can be never be smaller than

$$
\text { power }>1-\int_{2\left(\Delta \sqrt{n}-d_{\alpha} \sqrt{n}\right)}^{2\left(\Delta \sqrt{n}+d_{\alpha} \sqrt{n}\right)} \frac{1}{\sqrt{2 \pi}} e^{-\frac{t^{2}}{2}} d t
$$

This reduced expression can be used to calculate the number of samples required to reject the null hypothesis with a desired power. Figure 13.6 shows 
the power of the $\mathrm{D}$ test for $1 \%, 5 \%$, and $10 \%$ levels of confidence of the test for samples size larger than 35 (Massey, 1951). For example, assume that the maximum distance between the alternative cumulative and the estimated cumulative probability distributions is 0.2 , and we want an $80 \%$ power against the alternative at a $5 \%$ level of confidence. To calculate the number of required samples, we read that $\Delta N^{0.5}$ is 1.8 for a power of 0.8 and $5 \%$ level of confidence. Solving for $N=(1.8 / 0.2)^{2}=81$ samples. If we want to calculate the number of samples when the difference between the alternative cumulative and the estimated cumulative probability function is 0.05 , with the same power and level of confidence, then 1,296 samples would be required. When the lines are very close together, it is obviously very difficult to statistically show that they are different.

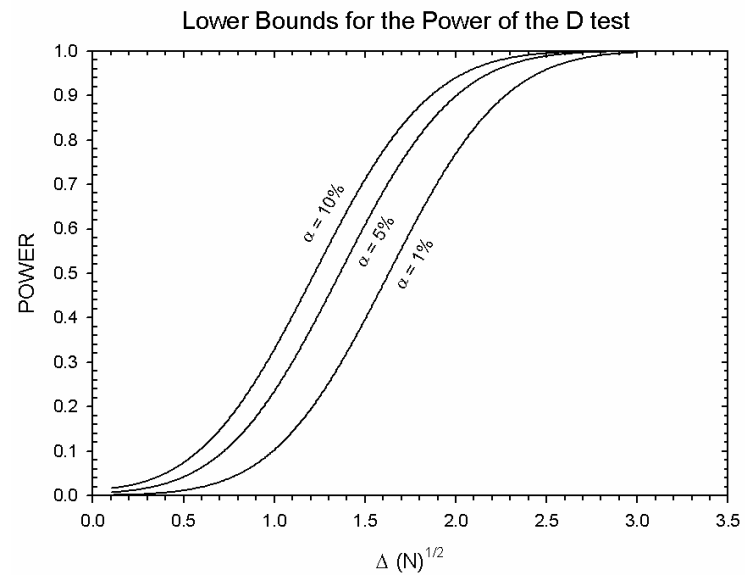

Figure 13.6 Lower bounds for the power of the $D$ test for $\alpha=1 \%, 5 \%$ and $10 \%$. $(\mathrm{N}>35)$.

In the NSQD, most of the data were from residential land uses. The Kolmogorov-Smirnov test was used to indicate if the cumulative empirical probability distribution of the residential stormwater constituents can be adequately represented with a lognormal distribution. Table 13.1 shows the resulting power of the test for $\Delta=0.05$ and $\Delta=0.1$, when applied to selected constituents that had very high levels of detection in residential land uses.

Table 13.1 shows that the number of collected samples is sufficient to detect if the empirical distribution is located inside an interval of width 0.1 above and below the estimated cumulative probability distribution. If the 
interval is reduced to 0.05 , the power varies between 40 and $65 \%$. To estimate the interval width, 10 cumulative distributions of 1,000 random data points, having a lognormal $(1,1)$ distribution, were compared with the estimated cumulative distribution for normal, gamma and exponential distributions. The maximum distance between the cumulative lognormal and the cumulative normal distributions was 0.25 . The maximum distance with cumulative gamma (the same for exponential in this case) was 0.28. An interval width of 0.1 was considered appropriate for the analysis.

Table 13.1 Power of the test when applied to selected constituents in residential land uses.

\begin{tabular}{lcccccc}
\hline Constituent & $\mathrm{N}$ & $\begin{array}{c}\% \\
\text { Detected }\end{array}$ & $\begin{array}{c}\Delta \mathrm{N}^{0.5} \\
(\Delta=0.05)\end{array}$ & $\begin{array}{c}\text { Power } \\
(\Delta=0.05 \\
\alpha=5 \%)\end{array}$ & $\begin{array}{c}\Delta \mathrm{N}^{0.5} \\
(\Delta=0.1)\end{array}$ & $\begin{array}{c}\text { Power } \\
(\Delta=0.1 \\
\alpha=5 \%)\end{array}$ \\
\hline TDS $(\mathrm{mg} / \mathrm{L})$ & 861 & 99.2 & 1.46 & 0.60 & 2.92 & 1 \\
TSS $(\mathrm{mg} / \mathrm{L})$ & 991 & 98.6 & 1.56 & 0.65 & 3.12 & 1 \\
BOD $(\mathrm{mg} / \mathrm{L})$ & 941 & 97.6 & 1.52 & 0.65 & 3.04 & 1 \\
COD $(\mathrm{mg} / \mathrm{L})$ & 796 & 98.9 & 1.40 & 0.55 & 2.80 & 1 \\
NO2+NO3 $(\mathrm{mg} / \mathrm{L})$ & 927 & 97.4 & 1.50 & 0.60 & 3.00 & 1 \\
TKN $(\mathrm{mg} / \mathrm{L})$ & 957 & 96.8 & 1.52 & 0.65 & 3.04 & 1 \\
TP $(\mathrm{mg} / \mathrm{L})$ & 963 & 96.9 & 1.53 & 0.65 & 3.06 & 1 \\
Total Copper $(\mu \mathrm{g} / \mathrm{L})$ & 799 & 83.6 & 1.29 & 0.50 & 2.58 & 1 \\
Total Lead $(\mu \mathrm{g} / \mathrm{L})$ & 788 & 71.3 & 1.19 & 0.40 & 2.38 & 1 \\
\hline Total Zinc $(\mu \mathrm{g} / \mathrm{L})$ & 810 & 96.4 & 1.40 & 0.55 & 2.80 & 1 \\
\hline
\end{tabular}

Another factor that must be considered is the importance of relatively small errors in the selected distribution and the problems of a false negative determination. It may not be practical to collect as many data observations as needed when the distributions are close (such as when the width interval is 0.05). Therefore, it is important to understand what types of further statistical and analysis problems may be caused by having fewer samples than optimal. For example, Figure 13.7 (Total phosphorus in residential area) shows that most of the data fall along the straight line (indicating a lognormal fit), with fewer than 10 observations (out of 933) in the tails being outside of the obvious path of the line.

The calculated p-value for the Kolmogorov-Smirnov test is 0.022 , indicating that the null hypothesis could be rejected and that there is not enough evidence that the empirical distribution is adequately represented by a lognormal distribution. Notice that errors in the tails are smaller than 0.049. 
However, the tails are not responsible for the rejection of the null hypothesis (See Figure 13.8).

In this case, $\mathrm{D}_{\max }$ is located close to a total phosphorus concentration of $0.2 \mathrm{mg} / \mathrm{L}$ (-0.7 in log scale). As in this case, the hypothesized distributions are usually rejected because of the departures in the middle of the distribution, not in the tails. However, as previously pointed out, a small number of observations in the upper tail can change the shape of the estimated cumulative probability distribution by affecting the mean and standard deviation of the data.

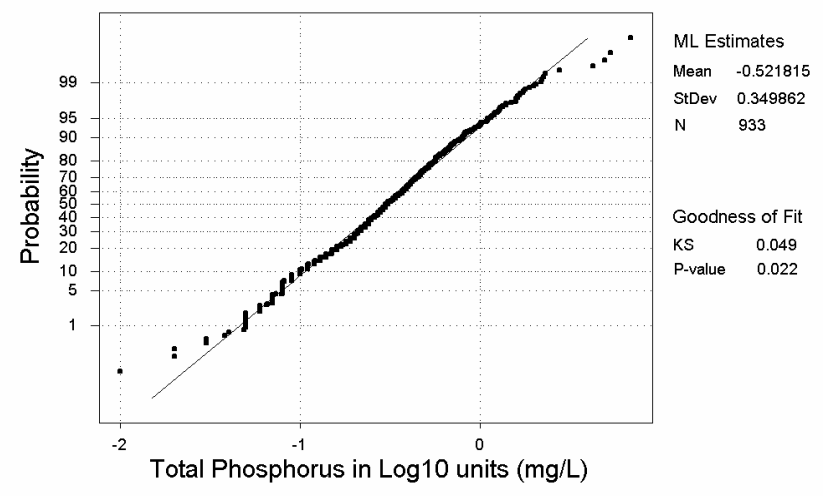

Figure 13.7 Normality test for Total Phosphorus in residential land uses using the NSQD (ML estimates.

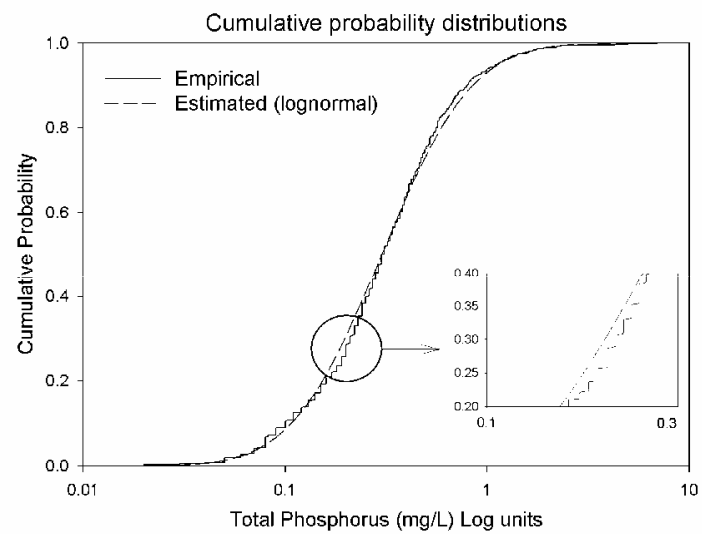

Figure 13.8 $D_{\max }$ was located in the middle of the distribution. 
The methods used previously by Van Buren and Beherra evaluated the probability distributions only using two parameters, the median and the standard deviation. They suggested the gamma and exponential distribution as alternatives to the lognormal for some stormwater constituents. Table 13.2 shows the comparison for the goodness of fit using the two parameter gamma, exponential and lognormal distributions using the method of moments.

Table 13.2 shows that for residential, commercial and industrial land uses, the lognormal distribution better fits the empirical data, except for selenium and silver in commercial land uses. In open space land uses, about $50 \%$ of the constituents were adequately fitted by the lognormal distribution, $30 \%$ by the gamma distribution and the remaining by the exponential distribution. In freeway areas, lognormal distributions better fit most of the constituents, except that fecal streptococcus, total arsenic and total chromium were better fitted by the gamma distribution and ammonia was better fitted by the exponential distribution. Also note in Table 13.2 that residential, commercial and industrial land uses had larger sample sizes than the other two land uses. It seems that for small sample sizes, gamma and exponential distributions better represent actual stormwater constituent distributions, but once the number of samples increases, the lognormal distribution is best. The few cases were the gamma distribution was a better fit was for $\mathrm{NO}_{2}+\mathrm{NO}_{3}$ in industrial land uses, and chromium in freeway areas. The exponential distribution better represents total ammonia in freeway areas (with around 70 detected samples) than the other two distribution types. Table 13.2 covers the next several pages.

Table 13.2 Comparison of goodness of fit for gamma, exponential and lognormal distributions using the NSQD v.1.1.

\begin{tabular}{|c|c|c|c|c|c|c|c|c|c|c|}
\hline \multirow{2}{*}{$\begin{array}{l}\text { CONST- } \\
\text { ITUENT }\end{array}$} & \multirow[t]{2}{*}{ PDF } & \multicolumn{3}{|c|}{ RESIDENTIAL } & \multicolumn{3}{|c|}{ COMMERCIAL } & \multicolumn{3}{|c|}{ INDUSTRIAL } \\
\hline & & $\mathrm{N}_{\text {Det }}$ & Dmax & $\begin{array}{l}\text { P- } \\
\text { value }\end{array}$ & $\mathrm{N}_{\text {Det }}$ & Dmax & $\begin{array}{l}P \text { - } \\
\text { value }\end{array}$ & $\mathrm{N}_{\text {Det }}$ & Dmax & $\begin{array}{l}\mathrm{P} \text { - } \\
\text { value }\end{array}$ \\
\hline \multirow{6}{*}{ 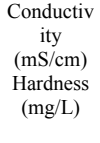 } & Gamma & 106 & 0.381 & 0 & 66 & 0.230 & 0.002 & 108 & 0.348 & 0 \\
\hline & Exponential & \multirow{2}{*}{$100 \%$} & 0.195 & 0.001 & \multirow{2}{*}{100} & 0.237 & 0.001 & \multirow{2}{*}{100} & 0.228 & 0 \\
\hline & Lognormal & & 0.081 & 0.493 & & 0.100 & 0.530 & & 0.074 & 0.619 \\
\hline & Gamma & 250 & 0.217 & 0 & 139 & 0.141 & 0.008 & 138 & 0.323 & 0 \\
\hline & Exponential & \multirow[t]{2}{*}{$100 \%$} & 0.203 & 0 & 100 & 0.115 & 0.067 & \multirow[t]{2}{*}{96.4} & 0.133 & 0.018 \\
\hline & Lognormal & & 0.071 & 0.166 & & 0.090 & 0.206 & & 0.080 & 0.369 \\
\hline Oil and & Gamma & 533 & 0.876 & 0 & 308 & 0.629 & 0 & 327 & 0.939 & 0 \\
\hline Grease & Exponential & \multirow[t]{2}{*}{$57.8 \%$} & 0.514 & 0 & 70.8 & 0.304 & 0 & \multirow[t]{2}{*}{65.1} & 0.697 & 0 \\
\hline$(\mathrm{mg} / \mathrm{L})$ & Lognormal & & 0.112 & 0.001 & & 0.103 & 0.019 & & 0.098 & 0.032 \\
\hline Total & Gamma & 861 & 0.234 & 0 & 399 & 0.457 & 0 & \multirow{3}{*}{$\begin{array}{l}413 \\
99.5\end{array}$} & 0.645 & 0 \\
\hline Dissolved & Exponential & \multirow[t]{2}{*}{$99.3 \%$} & 0.207 & 0 & 99.5 & 0.150 & 0 & & 0.172 & 0 \\
\hline $\begin{array}{l}\text { Solids } \\
(\mathrm{mg} / \mathrm{L})\end{array}$ & Lognormal & & 0.050 & 0.029 & & 0.049 & 0.303 & & 0.066 & 0.053 \\
\hline Total & Gamma & 991 & 0.288 & 0 & 458 & 0.363 & 0 & 428 & 0.206 & 0 \\
\hline \multirow{3}{*}{$\begin{array}{c}\text { Suspende } \\
\text { d Solids } \\
(\mathrm{mg} / \mathrm{L}) \\
\text { BOD5 }\end{array}$} & Exponential & \multirow[t]{2}{*}{$98.6 \%$} & 0.141 & 0 & \multirow[t]{2}{*}{98.3} & 0.214 & 0 & \multirow[t]{2}{*}{99.1} & 0.108 & 0 \\
\hline & Lognormal & & 0.032 & 0.280 & & 0.064 & 0.053 & & 0.029 & 0.995 \\
\hline & Gamma & 941 & 0.321 & 0 & 432 & 0.191 & 0 & 406 & 0.921 & 0 \\
\hline
\end{tabular}




\begin{tabular}{|c|c|c|c|c|c|c|c|c|c|c|}
\hline$(\mathrm{mg} / \mathrm{L})$ & Exponential & $97.6 \%$ & 0.140 & 0 & 97.5 & 0.142 & 0 & 95.3 & 0.355 & 0 \\
\hline & Lognormal & & 0.058 & 0.004 & & 0.054 & 0.166 & & 0.105 & 0 \\
\hline COD & Gamma & 796 & 0.129 & 0 & 373 & 0.137 & 0 & 362 & 0.216 & 0 \\
\hline \multirow[t]{2}{*}{$(\mathrm{mg} / \mathrm{L})$} & Exponential & $98.9 \%$ & 0.161 & 0 & 98.4 & 0.136 & 0 & 98.9 & 0.119 & 0 \\
\hline & Lognormal & & 0.036 & 0.250 & & 0.038 & 0.695 & & 0.074 & 0.040 \\
\hline Fecal & Gamma & 446 & 0.655 & 0 & 233 & 0.333 & 0 & 297 & - & - \\
\hline Coliform & Exponential & $88.3 \%$ & 0.374 & 0 & 88 & 0.396 & 0 & 87.9 & 0.504 & 0 \\
\hline $\begin{array}{c}\text { (Colonies/ } \\
100 \mathrm{~mL} \text { ) }\end{array}$ & Lognormal & & 0.080 & 0.013 & & 0.076 & 0.192 & & 0.051 & 0.510 \\
\hline Fecal & Gamma & 305 & 0.158 & 0 & 181 & 0.354 & 0 & 195 & - & - \\
\hline Strep & Exponential & $89.5 \%$ & 0.202 & 0 & 91.7 & 0.278 & 0 & 93.8 & 0.399 & 0 \\
\hline $\begin{array}{c}\text { (Colonies/ } \\
100 \mathrm{~mL} \text { ) }\end{array}$ & Lognormal & & 0.077 & 0.081 & & 0.097 & 0.091 & & 0.083 & 0.161 \\
\hline \multirow{3}{*}{$\begin{array}{c}\text { Ammonia } \\
(\mathrm{mg} / \mathrm{L})\end{array}$} & Gamma & 595 & 0.132 & 0 & 299 & 0.131 & 0 & 254 & 0.154 & 0 \\
\hline & Exponential & $81.5 \%$ & 0.101 & 0 & 83.3 & 0.066 & 0.228 & 85.8 & 0.071 & 0.221 \\
\hline & Lognormal & & 0.044 & 0.305 & & 0.050 & 0.589 & & 0.047 & 0.758 \\
\hline $\mathrm{NO} 2+\mathrm{NO}$ & Gamma & 927 & 0.197 & 0 & 425 & 0.147 & 0 & 418 & 0.080 & 0.011 \\
\hline \multirow[t]{2}{*}{$3(\mathrm{mg} / \mathrm{L})$} & Exponential & $97.4 \%$ & 0.141 & 0 & 98.1 & 0.120 & 0 & 96.2 & 0.132 & 0 \\
\hline & Lognormal & & 0.070 & 0 & & 0.040 & 0.531 & & 0.080 & 0.011 \\
\hline TKN & Gamma & 957 & 0.203 & 0 & 449 & 0.127 & 0 & 440 & 0.195 & 0 \\
\hline \multirow[t]{2}{*}{$(\mathrm{mg} / \mathrm{L})$} & Exponential & $96.8 \%$ & 0.182 & 0 & 97.3 & 0.156 & 0 & 95.9 & 0.134 & 0 \\
\hline & Lognormal & & 0.035 & 0.218 & & 0.042 & 0.423 & & 0.048 & 0.292 \\
\hline Dissolved & Gamma & 738 & 0.117 & 0 & 323 & 0.177 & 0 & 325 & 0.200 & 0 \\
\hline Phosphor & Exponential & 84.1 & 0.144 & 0 & 81.1 & 0.129 & 0 & 87.1 & 0.135 & 0 \\
\hline us (mg/L) & Lognormal & & 0.043 & 0.199 & & 0.075 & 0.104 & & 0.124 & 0.682 \\
\hline Total & Gamma & 963 & 0.184 & 0 & 446 & 0.179 & 0 & 434 & 0.227 & 0 \\
\hline Phosphor & Exponential & 96.9 & 0.129 & 0 & 95.7 & 0.114 & 0 & 96.3 & 0.107 & 0 \\
\hline us $(\mathrm{mg} / \mathrm{L})$ & Lognormal & & 0.049 & 0.022 & & 0.038 & 0.582 & & 0.049 & 0.273 \\
\hline Total & Gamma & 288 & 0.268 & 0.636 & 142 & - & - & 164 & 0.282 & 0.045 \\
\hline \multirow{2}{*}{$\begin{array}{c}\text { Antimony } \\
(\mu \mathrm{g} / \mathrm{L})\end{array}$} & Exponential & 2.8 & 0.417 & 0.213 & 2.1 & - & - & 14.6 & 0.173 & 0.473 \\
\hline & Lognormal & & 0.233 & 0.841 & & - & - & & 0.096 & 1.279 \\
\hline Total & Gamma & 426 & 0.531 & 0 & 213 & 0.643 & 0 & 267 & 0.291 & 0 \\
\hline Arsenic & Exponential & 42 & 0.224 & 0 & 32.9 & 0.249 & 0 & 54.3 & 0.141 & 0.006 \\
\hline$(\mu \mathrm{g} / \mathrm{L})$ & Lognormal & & 0.154 & 0 & & 0.164 & 0.046 & & 0.129 & 0.016 \\
\hline Total & Gamma & 301 & 0.464 & 0 & 163 & 0.305 & 0.542 & 209 & 0.390 & 0.002 \\
\hline \multirow{3}{*}{$\begin{array}{c}\text { Beryllium } \\
(\mu \mathrm{g} / \mathrm{L})\end{array}$} & Exponential & 7.3 & 0.471 & 0 & 4.29 & 0.530 & 0.039 & 10.5 & 0.539 & 0 \\
\hline & Lognormal & & 0.200 & 0.342 & & 0.205 & 1.108 & & 0.163 & 0.620 \\
\hline & Gamma & 723 & 0.643 & 0 & 358 & 0.511 & 0 & 395 & 0.445 & 0 \\
\hline \multirow{2}{*}{$\begin{array}{l}\text { Cadmium } \\
(\mu \mathrm{g} / \mathrm{L})\end{array}$} & Exponential & 30.3 & 0.358 & 0 & 43 & 0.311 & 0 & 49.4 & 0.237 & 0 \\
\hline & Lognormal & & 0.120 & 0.004 & & 0.113 & 0.039 & & 0.083 & 0.136 \\
\hline Total & Gamma & 435 & 0.292 & 0 & 235 & 0.151 & 0.004 & 256 & 0.122 & 0.008 \\
\hline \multirow{2}{*}{$\begin{array}{l}\text { Chromiu } \\
\mathrm{m}(\mu \mathrm{g} / \mathrm{L})\end{array}$} & Exponential & 55.4 & 0.132 & 0 & 58.7 & 0.201 & 0 & 72.7 & 0.067 & 0.381 \\
\hline & Lognormal & & 0.069 & 0.206 & & 0.086 & 0.262 & & 0.062 & 0.480 \\
\hline Total & Gamma & 799 & 0.394 & 0 & 387 & 0.296 & 0 & 416 & 0.408 & 0 \\
\hline \multirow{2}{*}{$\begin{array}{l}\text { Copper } \\
(\mu \mathrm{g} / \mathrm{L})\end{array}$} & Exponential & 83.6 & 0.149 & 0 & 92.8 & 0.137 & 0 & 89.9 & 0.177 & 0 \\
\hline & Lognormal & & 0.067 & 0.005 & & 0.070 & 0.060 & & 0.080 & 0.017 \\
\hline Total & Gamma & 788 & 0.300 & 0 & 377 & 0.297 & 0 & 412 & 0.276 & 0 \\
\hline \multirow{2}{*}{$\begin{array}{c}\text { Lead } \\
(\mu \mathrm{g} / \mathrm{L})\end{array}$} & Exponential & 71.3 & 0.173 & 0 & 85.4 & 0.136 & 0 & 76.5 & 0.225 & 0 \\
\hline & Lognormal & & 0.044 & 0.218 & & 0.057 & 0.250 & & 0.059 & 0.223 \\
\hline \multirow{3}{*}{$\begin{array}{l}\text { Total } \\
\text { Nickel } \\
(\mu \mathrm{g} / \mathrm{L})\end{array}$} & Gamma & 419 & 0.292 & 0 & 232 & 0.260 & 0 & 250 & 0.090 & 0.159 \\
\hline & Exponential & 45.3 & 0.203 & 0 & 59.5 & 0.176 & 0 & 62.4 & 0.111 & 0.044 \\
\hline & Lognormal & & 0.081 & 0.160 & & 0.056 & 0.831 & & 0.065 & 0.525 \\
\hline & Gamma & 318 & 0.263 & 0.095 & 169 & 0.169 & 0.952 & 203 & 0.434 & 0.022 \\
\hline \multirow{2}{*}{$\begin{array}{c}\text { Selenium } \\
(\mu \mathrm{g} / \mathrm{L})\end{array}$} & Exponential & 6.9 & 0.254 & 0.117 & 7.7 & 0.174 & 0.907 & 5.9 & 0.256 & 0.416 \\
\hline & Lognormal & & 0.253 & 0.119 & & 0.196 & 0.735 & & 0.190 & 0.841 \\
\hline Total & Gamma & 406 & 0.421 & 0 & 222 & 0.143 & 0.718 & 287 & 0.263 & 0.002 \\
\hline \multirow{2}{*}{$\begin{array}{l}\text { Silver } \\
(\mu \mathrm{g} / \mathrm{L})\end{array}$} & Exponential & 12.6 & 0.333 & 0 & 11.3 & 0.159 & 0.563 & 17.4 & 0.340 & 0 \\
\hline & Lognormal & & 0.271 & 0.001 & & 0.184 & 0.370 & & 0.146 & 0.236 \\
\hline \multirow{3}{*}{$\begin{array}{c}\text { Total Zinc } \\
(\mu \mathrm{g} / \mathrm{L})\end{array}$} & Gamma & 810 & 0.244 & 0 & 392 & 0.234 & 0 & 433 & 0.273 & 0 \\
\hline & Exponential & 96.4 & 0.122 & 0 & 99 & 0.141 & 0 & 98.6 & 0.083 & 0.005 \\
\hline & Lognormal & & 0.054 & 0.020 & & 0.040 & 0.585 & & 0.044 & 0.389 \\
\hline
\end{tabular}

* P-values greater than one are used only for comparison. NDet: Number of collected samples and percentage detected 
Table 13.2 continued Comparison of goodness of fit for gamma, exponential and lognormal distributions using the NSQD v.1.1.

\begin{tabular}{|c|c|c|c|c|c|c|c|}
\hline \multirow{2}{*}{$\begin{array}{l}\text { CONST- } \\
\text { ITUENT }\end{array}$} & \multirow[t]{2}{*}{ PDF } & \multicolumn{3}{|c|}{ OPEN SPACE } & \multicolumn{3}{|c|}{ FREEWAYS } \\
\hline & & $\mathrm{N}_{\text {Det }}$ & Dmax & $\begin{array}{l}\mathrm{P}- \\
\text { value }\end{array}$ & $\mathrm{N}_{\text {Det }}$ & Dmax & $\begin{array}{l}\mathrm{P}- \\
\text { value }\end{array}$ \\
\hline \multirow{6}{*}{$\begin{array}{c}\text { Conductiv } \\
\text { ity } \\
(\mathrm{mS} / \mathrm{cm}) \\
\text { Hardness } \\
(\mathrm{mg} / \mathrm{L})\end{array}$} & Gamma & 2 & - & - & 86 & 0.238 & 0 \\
\hline & Exponential & \multirow{2}{*}{100} & - & - & \multirow{2}{*}{100} & 0.232 & 0 \\
\hline & Lognormal & & - & - & & 0.129 & 0.113 \\
\hline & Gamma & 8 & 0.304 & 0.458 & 127 & 0.451 & 0 \\
\hline & Exponential & \multirow[t]{2}{*}{100} & 0.369 & 0.228 & \multirow[t]{2}{*}{100} & 0.161 & 0.003 \\
\hline & Lognormal & & 0.354 & 0.268 & & 0.077 & 0.447 \\
\hline Oil and & Gamma & 19 & 0.210 & 1.080 & 60 & 0.103 & 0.810 \\
\hline Grease & Exponential & \multirow{2}{*}{36.84} & 0.265 & 0.750 & \multirow{2}{*}{71.7} & 0.286 & 0.002 \\
\hline$(\mathrm{mg} / \mathrm{L})$ & Lognormal & & 0.202 & 1.127 & & 0.101 & 0.827 \\
\hline Total & Gamma & 45 & 0.109 & 0.698 & 97 & 0.082 & 0.553 \\
\hline Dissolved & Exponential & \multirow{2}{*}{97.8} & 0.195 & 0.070 & \multirow[t]{2}{*}{99} & 0.171 & 0.007 \\
\hline $\begin{array}{l}\text { Solids } \\
(\mathrm{mg} / \mathrm{L})\end{array}$ & Lognormal & & 0.120 & 0.561 & & 0.054 & 1.136 \\
\hline Total & Gamma & 44 & 0.132 & 0.464 & 134 & 0.534 & 0 \\
\hline Suspende & Exponential & \multirow[t]{2}{*}{95.5} & 0.289 & 0.002 & \multirow[t]{2}{*}{99.3} & 0.168 & 0.011 \\
\hline $\begin{array}{c}\text { d Solids } \\
(\mathrm{mg} / \mathrm{L})\end{array}$ & Lognormal & & 0.113 & 0.683 & & 0.066 & 0.627 \\
\hline BOD5 & Gamma & 44 & 0.112 & 0.770 & 26 & 0.272 & 0.076 \\
\hline \multirow[t]{2}{*}{$(\mathrm{mg} / \mathrm{L})$} & Exponential & \multirow[t]{2}{*}{86.4} & 0.261 & 0.011 & \multirow[t]{2}{*}{84.6} & 0.168 & 0.580 \\
\hline & Lognormal & & 0.114 & 0.746 & & 0.103 & 1.252 \\
\hline COD & Gamma & 43 & 0.373 & 0 & 67 & 0.163 & 0.061 \\
\hline \multirow{2}{*}{$(\mathrm{mg} / \mathrm{L})$} & Exponential & 76.7 & 0.168 & 0.312 & 98.5 & 0.139 & 0.157 \\
\hline & Lognormal & & 0.128 & 0.684 & & 0.107 & 0.445 \\
\hline Fecal & Gamma & 23 & 0.179 & 0.520 & 49 & 0.239 & 0.007 \\
\hline Coliform & Exponential & 91.3 & 0.208 & 0.324 & 100 & 0.355 & 0 \\
\hline $\begin{array}{c}\text { (Colonies/ } \\
100 \mathrm{~mL} \text { ) }\end{array}$ & Lognormal & & 0.181 & 0.503 & & 0.105 & 0.677 \\
\hline Fecal & Gamma & 22 & 0.144 & 0.869 & 25 & 0.096 & 1.262 \\
\hline Strep & Exponential & 90.9 & 0.142 & 0.892 & 100 & 0.164 & 0.518 \\
\hline $\begin{array}{c}\text { (Colonies/ } \\
100 \mathrm{~mL} \text { ) }\end{array}$ & Lognormal & & 0.181 & 0.538 & & 0.119 & 0.990 \\
\hline Ammonia & Gamma & 32 & - & - & 79 & 0.216 & 0.003 \\
\hline$(\mathrm{mg} / \mathrm{L})$ & Exponential & 18.7 & - & - & 87.3 & 0.105 & 0.440 \\
\hline & Lognormal & & - & - & & 0.133 & 0.173 \\
\hline $\mathrm{NO} 2+\mathrm{NO}$ & Gamma & 44 & 0.123 & 0.654 & 25 & 0.274 & 0.055 \\
\hline $3(\mathrm{mg} / \mathrm{L})$ & Exponential & 841 & 0.120 & 0.686 & 96 & 0.177 & 0.443 \\
\hline & Lognormal & & 0.141 & 0.463 & & 0.139 & 0.789 \\
\hline TKN & Gamma & 45 & 0.169 & 0.323 & 125 & 0.280 & 0 \\
\hline$(\mathrm{mg} / \mathrm{L})$ & Exponential & 71.1 & 0.141 & 0.556 & 96.8 & 0.138 & 0.020 \\
\hline & Lognormal & & 0.147 & 0.500 & & 0.074 & 0.539 \\
\hline Dissolved & Gamma & 44 & 0.154 & 0.127 & 22 & 0.449 & 0 \\
\hline Phosphor & Exponential & 79.5 & 0.384 & 0.657 & 95.5 & 0.350 & 0.012 \\
\hline us $(\mathrm{mg} / \mathrm{L})$ & Lognormal & & 0.124 & 0.682 & & 0.170 & 0.593 \\
\hline Total & Gamma & 46 & 0.666 & 0 & 128 & 0.456 & 0 \\
\hline Phosphor & Exponential & 84.8 & 0.320 & 0.001 & 99.2 & 0.187 & 0 \\
\hline us $(\mathrm{mg} / \mathrm{L})$ & Lognormal & & 0.116 & 0.696 & & 0.085 & 0.325 \\
\hline Total & Gamma & 17 & - & - & 14 & 0.423 & 0.164 \\
\hline Antimony & Exponential & 0 & - & - & 50 & 0.465 & 0.096 \\
\hline$(\mu \mathrm{g} / \mathrm{L})$ & Lognormal & & - & - & & 0.419 & 0.171 \\
\hline Total & Gamma & 19 & 0.271 & 0.828 & 61 & 0.125 & 0.694 \\
\hline Arsenic & Exponential & 31.6 & 0.462 & 0.154 & 55.7 & 0.266 & 0.016 \\
\hline$(\mu \mathrm{g} / \mathrm{L})$ & Lognormal & & 0.273 & 0.819 & & 0.149 & 0.441 \\
\hline Total & Gamma & 19 & - & - & 12 & - & - \\
\hline Beryllium & Exponential & 0 & - & - & 16.7 & - & - \\
\hline$(\mu \mathrm{g} / \mathrm{L})$ & Lognormal & & - & - & & - & - \\
\hline
\end{tabular}

* P-values greater than one are used only for comparison.

NDet: Number of collected samples and percentage detected 
Other transformations were also tested, such as the square root, and other power functions, but the results were not improved. It was therefore decided to investigate if a three-parameter lognormal distribution function can be used to improve the overall goodness of fit for stormwater constituent probability distributions. As shown in the following section, this third parameter, in some cases, allows a much better fit of the cumulative empirical and estimated probability distributions.

\subsection{Three Parameter Lognormal Calculations}

Goodness of fit was evaluated using three-parameter lognormal probability distribution. The probability distributions were created for residential, commercial, industrial, open space, and freeways land uses. The distribution parameters were calculated using the maximum likelihood and the L-moments methods. The maximum likelihood method requires that it be solved iteratively using three equations. The initial parameters were obtained using the method of moments. The results were compared with the two parameter standard model and the data. The model with the smaller maximum distance between the empirical and the estimated function was selected as the best model. All the calculations were made using only the detected values. The percentage of non-detected values was also calculated for each dataset.

In general, the L-moments method provided a better fit for the upper tail of the distribution whereas the maximum likelihood method provided a better fit for the lower tail. Figure 13.9 shows the three estimated models for TSS in industrial land uses.

In this graph it is observed that the empirical distribution has higher values in the upper tail compared with any of the three models. In the lower tail, the maximum likelihood method using the three parameters better fit the observed values best. In this case the maximum likelihood method was better than the other two models, although none of the methods adequately represented the extreme high values.

The L-moments method generally betters fits the upper tail distribution, but typically trims or overestimate the lower tail. Figure 13.10 shows the results for TDS in industrial land uses. The L-moments better fits the empirical distribution in the upper tail, but it trims any observation smaller than $35 \mathrm{mg} / \mathrm{L}$ (almost $20 \%$ of the total dataset) in the lower tail. The two parameter lognormal and the maximum likelihood method provide better results although both were worse in the more critical upper tail region. 


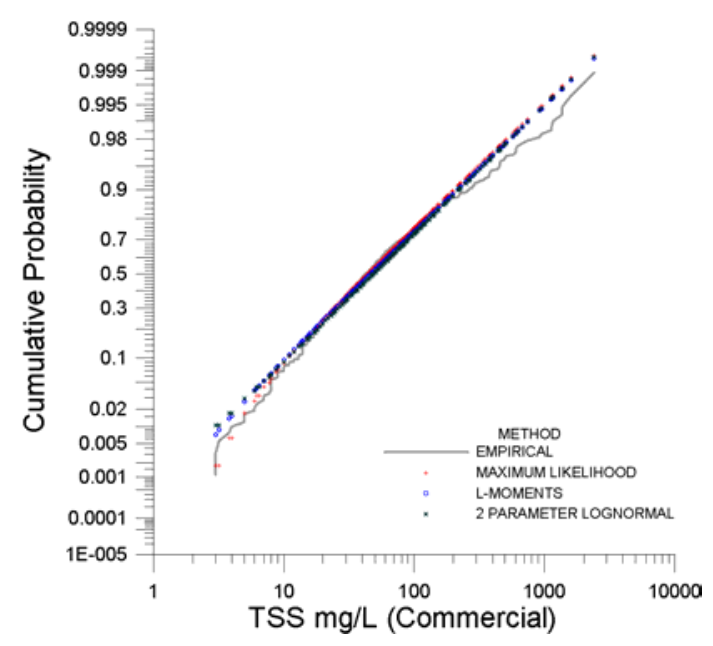

Figure 13.9 Estimated models for TSS in commercial land uses probability plot.

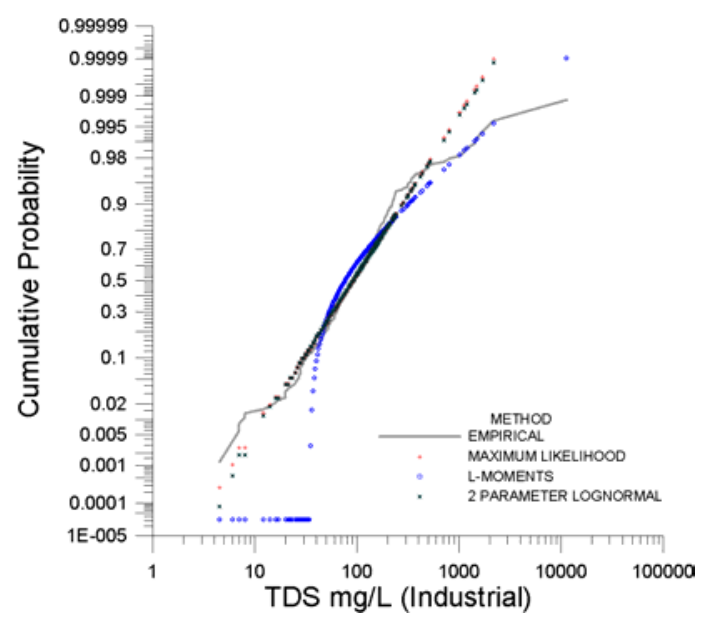

Figure 13.10 Estimated models for TDS in industrial land uses probability plot.

The results for 15 constituents in five land uses are shown in Table 13.3. For each of the three methods, the p-value was calculated. The higher the p-value, 
the better is the fit between the empirical and the estimated function. Some of the p-values are larger than one. When the number of samples is large, the pvalue is calculated as a chi square distribution with 2 degrees of freedom. This probability is calculated only with one tail of the chi square distribution. The p-value is two times this probability. The maximum p-value is one, but for effects of comparison this presents two times the probability calculated from a one tail chi square distribution.

The maximum likelihood method with 3 parameters, and the lognormal two parameter distribution, produced the best descriptions for most of the constituents. For almost all constituents the function estimated by the Lmoments method failed the lognormal assumption. Low p-values were obtained because the function was truncated and does not estimate the lower tail of the distribution.

It seems that when the numbers of samples increase, the L-moments method tends to truncate the function. The maximum likelihood method seems to improve the fit of the distribution, but when the number of samples is large, the cumulative estimated probability distribution is far from the cumulative empirical probability distribution, or no convergence is possible during the iteration process.

In commercial, industrial and freeways land uses, the numbers of samples available were between 100 and 500 samples. According to the prior discussion, this number of samples will result in an analysis having a power close or above 0.5 . In these cases, most of the better fits were obtained using the L-moments method. In commercial and industrial land uses, more than half of the constituents also had the highest p-values when the L-moments method was used.

In open space areas, there were not many samples available. The small number of samples results in a low power. In this case, the higher p-values results were observed when the two parameter lognormal distribution was used. The use of the third parameter in constituents having small numbers of sample observations did not improve the fit of the estimated cumulative probability distribution.

Table 13.3 follows on the next and consecutive pages. 
Table 13.3 Goodness of fit for different land uses.

\begin{tabular}{|c|c|c|c|c|c|c|c|}
\hline \multirow[t]{2}{*}{ CONSTITUENT } & \multirow[t]{2}{*}{$\mathrm{N}$} & \multirow[t]{2}{*}{$\begin{array}{l}\% \\
\text { Det }\end{array}$} & \multicolumn{2}{|c|}{$\begin{array}{c}\text { Sample } \\
\text { Parameters }\end{array}$} & \multirow[t]{2}{*}{ PDF } & \multicolumn{2}{|c|}{ RESIDENTIAL } \\
\hline & & & Mean & $\mathrm{S}$ & & Dmax & P-Value \\
\hline \multirow{4}{*}{$\begin{array}{l}\text { Conductivity } \\
(\mu \mathrm{S} / \mathrm{cm})\end{array}$} & \multirow{4}{*}{106} & \multirow{4}{*}{100} & \multirow{4}{*}{4.638} & \multirow{4}{*}{0.710} & 2-Parameter Lognormal & 0.081 & 0.493 \\
\hline & & & & & 3-Maximum Likelihood & 0.052 & 1.133 \\
\hline & & & & & 3-Lmoments & 0.087 & 0.398 \\
\hline & & & & & 2-Parameter Lognormal & 0.071 & 0.166 \\
\hline \multirow[t]{2}{*}{ Hardness $(\mathrm{mg} / \mathrm{L})$} & \multirow[t]{2}{*}{250} & \multirow[t]{2}{*}{100} & \multirow[t]{2}{*}{3.497} & \multirow[t]{2}{*}{0.706} & 3-Maximum Likelihood & 0.066 & 0.231 \\
\hline & & & & & 3-Lmoments & 0.635 & 0.000 \\
\hline \multirow{3}{*}{$\begin{array}{l}\text { Oil \& Grease } \\
(\mathrm{mg} / \mathrm{L})\end{array}$} & \multirow{3}{*}{533} & \multirow{3}{*}{57.8} & \multirow{3}{*}{1.428} & \multirow{3}{*}{1.204} & 2-Parameter Lognormal & 0.112 & 0.001 \\
\hline & & & & & 3-Maximum Likelihood & 0.102 & 0.003 \\
\hline & & & & & 3-Lmoments & 0.208 & 0.000 \\
\hline \multirow{3}{*}{$\begin{array}{l}\text { Fecal Coliform } \\
(\mathrm{Col} / 100 \mathrm{ml})\end{array}$} & & & & & 2-Parameter Lognormal & 0.080 & 0.013 \\
\hline & 446 & 88.3 & 8.721 & 2.404 & 3-Maximum Likelihood & 0.078 & 0.017 \\
\hline & & & & & 3-Lmoments & 0.096 & 0.001 \\
\hline Fecal & & & & & 2-Parameter Lognormal & 0.077 & 0.081 \\
\hline Streptococcus & 305 & 89.5 & 9.834 & 1.880 & 3-Maximum Likelihood & 0.066 & 0.190 \\
\hline$(\mathrm{C} / 100 \mathrm{ml})$ & & & & & 3-Lmoments & 0.077 & 0.078 \\
\hline & & & & & 2-Parameter Lognormal & 0.044 & 0.305 \\
\hline Ammonia $(\mathrm{mg} / \mathrm{L})$ & 595 & 81.5 & -1.167 & 0.917 & 3-Maximum Likelihood & 0.139 & 0.000 \\
\hline & & & & & 3-Lmoments & & \\
\hline Dissolved & & & & & 2-Parameter Lognormal & 0.043 & 0.199 \\
\hline $\begin{array}{l}\text { Phosphorus } \\
\text { (mg/L) }\end{array}$ & 738 & 84.1 & -1.830 & 0.857 & $\begin{array}{l}\text { 3-Maximum Likelihood } \\
\text { 3-Lmoments }\end{array}$ & 0.327 & 0.000 \\
\hline & & & & & 2-Parameter Lognormal & 0.233 & 0.841 \\
\hline Antimony $(\mu \mathrm{g} / \mathrm{L})$ & 288 & 2.8 & 1.355 & 1.719 & 3-Maximum Likelihood & 0.368 & 0.228 \\
\hline & & & & & 3-Lmoments & 0.270 & 0.626 \\
\hline & & & & & 2-Parameter Lognormal & 0.154 & 0.000 \\
\hline Arsenic $(\mu \mathrm{g} / \mathrm{L})$ & 426 & 42 & 1.210 & 0.850 & 3-Maximum Likelihood & 0.166 & 0.000 \\
\hline & & & & & 3-Lmoments & 0.208 & 0.000 \\
\hline & & & & & 2-Parameter Lognormal & 0.200 & 0.342 \\
\hline Beryllium $(\mu \mathrm{g} / \mathrm{L})$ & 301 & 7.3 & 0.028 & 1.596 & 3-Maximum Likelihood & 0.186 & 0.436 \\
\hline & & & & & 3-Lmoments & 0.227 & 0.207 \\
\hline & & & & & 2-Parameter Lognormal & 0.120 & 0.004 \\
\hline I otal Cadmium & 723 & 30.3 & -0.353 & 1.219 & 3-Maximum Likelihood & 0.110 & 0.010 \\
\hline & & & & & 3-Lmoments & 0.093 & 0.045 \\
\hline & & & & & 2-Parameter Lognormal & 0.069 & 0.206 \\
\hline lotal Chromium & 435 & 55.4 & 1.579 & 0.892 & 3-Maximum Likelihood & 0.067 & 0.236 \\
\hline & & & & & 3-Lmoments & 0.066 & 0.242 \\
\hline & & & & & 2-Parameter Lognormal & 0.081 & 0.160 \\
\hline 10 (1) & 419 & 45.3 & 1.791 & 0.757 & 3-Maximum Likelihood & 0.083 & 0.147 \\
\hline & & & & & 3-Lmoments & 0.084 & 0.137 \\
\hline & & & & & 2-Parameter Lognormal & 0.253 & 0.119 \\
\hline 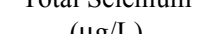 & 318 & 6.9 & 1.097 & 0.833 & 3-Maximum Likelihood & 0.259 & 0.061 \\
\hline & & & & & 3-Lmoments & 0.257 & 0.110 \\
\hline & & & & & 2-Parameter Lognormal & 0.271 & 0.001 \\
\hline Total Silver & 406 & 12.6 & 1.069 & 1.371 & 3-Maximum Likelihood & 0.278 & 0.001 \\
\hline & & & & & 3-Lmoments & 0.294 & 0.000 \\
\hline
\end{tabular}

* P-values $>1$ are used only for comparison. $\mathrm{N}$ : Number of collected samples. \%Det: percentage detected 
Table 13.3 continued Goodness of fit for different land uses.

\begin{tabular}{|c|c|c|c|c|c|c|c|}
\hline \multirow[t]{2}{*}{ CONSTITUENT } & \multirow[t]{2}{*}{$\mathrm{N}$} & \multirow[t]{2}{*}{$\begin{array}{l}\% \\
\text { Det }\end{array}$} & \multicolumn{2}{|c|}{$\begin{array}{c}\text { Sample } \\
\text { Parameters }\end{array}$} & \multirow[t]{2}{*}{ PDF } & \multicolumn{2}{|c|}{ COMMERCIAL } \\
\hline & & & Mean & $\mathrm{S}$ & & Dmax & P-Value \\
\hline \multirow{4}{*}{$\begin{array}{l}\text { Conductivity } \\
(\mu \mathrm{S} / \mathrm{cm})\end{array}$} & \multirow{4}{*}{66} & \multirow{4}{*}{100} & \multirow{4}{*}{4.779} & \multirow{4}{*}{0.721} & 2-Parameter Lognormal & 0.100 & 0.530 \\
\hline & & & & & 3-Maximum Likelihood & 0.097 & 0.581 \\
\hline & & & & & 3-Lmoments & 0.093 & 0.633 \\
\hline & & & & & 2-Parameter Lognormal & 0.090 & 0.206 \\
\hline \multirow[t]{2}{*}{ Hardness $(\mathrm{mg} / \mathrm{L})$} & \multirow[t]{2}{*}{139} & \multirow[t]{2}{*}{100} & \multirow[t]{2}{*}{3.689} & \multirow[t]{2}{*}{0.988} & 3-Maximum Likelihood & 0.063 & 0.653 \\
\hline & & & & & 3-Lmoments & 0.072 & 0.474 \\
\hline \multirow{4}{*}{$\begin{array}{l}\text { Oil \& Grease } \\
\quad(\mathrm{mg} / \mathrm{L})\end{array}$} & \multirow{4}{*}{308} & \multirow{4}{*}{70.8} & \multirow{4}{*}{1.609} & \multirow{4}{*}{1.070} & 2-Parameter Lognormal & 0.103 & 0.019 \\
\hline & & & & & 3-Maximum Likelihood & 0.092 & 0.062 \\
\hline & & & & & 3-Lmoments & 0.126 & 0.002 \\
\hline & & & & & 2-Parameter Lognormal & 0.049 & 0.303 \\
\hline TDS (mg/L) & 399 & 99.5 & 4.332 & 0.791 & 3-Maximum Likelihood & 0.049 & 0.289 \\
\hline & & & & & 3-Lmoments & 0.071 & 0.035 \\
\hline & & & & & 2-Parameter Lognormal & 0.064 & 0.053 \\
\hline TSS (mg/L) & 458 & 98.3 & 3.883 & 1.180 & 3-Maximum Likelihood & 0.042 & 0.416 \\
\hline & & & & & 3-Lmoments & 0.048 & 0.250 \\
\hline & & & & & 2-Parameter Lognormal & 0.054 & 0.166 \\
\hline BOD $(\mathrm{mg} / \mathrm{L})$ & 432 & 97.5 & 2.493 & 0.868 & 3-Maximum Likelihood & 0.040 & 0.527 \\
\hline & & & & & 3-Lmoments & 0.044 & 0.380 \\
\hline & & & & & 2-Parameter Lognormal & 0.038 & 0.695 \\
\hline $\mathrm{COD}(\mathrm{mg} / \mathrm{L})$ & 373 & 98.4 & 4.167 & 0.865 & 3-Maximum Likelihood & 0.037 & 0.719 \\
\hline & & & & & 3-Lmoments & 0.034 & 0.860 \\
\hline & & & & & 2-Parameter Lognormal & 0.076 & 0.192 \\
\hline$(\mathrm{Col} / 100 \mathrm{ml})$ & 233 & 88 & 8.202 & 2.380 & 3-Maximum Likelihood & 0.077 & 0.175 \\
\hline & & & & & 3-Lmoments & 0.150 & 0.000 \\
\hline Fecal & & & & & 2-Parameter Lognormal & 0.097 & 0.091 \\
\hline Streptococcus & 181 & 91.7 & 8.940 & 2.061 & 3-Maximum Likelihood & 0.096 & 0.093 \\
\hline$(\mathrm{C} / 100 \mathrm{ml})$ & & & & & 3-Lmoments & 0.056 & 0.702 \\
\hline & & & & & 2-Parameter Lognormal & 0.050 & 0.589 \\
\hline Ammonia $(\mathrm{mg} / \mathrm{L})$ & 299 & 83.3 & -0.706 & 1.083 & 3-Maximum Likelihood & 0.048 & 0.632 \\
\hline & & & & & 3-Lmoments & 0.040 & 0.888 \\
\hline & & & & & 2-Parameter Lognormal & 0.040 & 0.531 \\
\hline 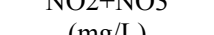 & 425 & 98.1 & -0.523 & 0.882 & 3-Maximum Likelihood & 0.034 & 0.837 \\
\hline & & & & & 3-Lmoments & 0.030 & 0.954 \\
\hline & & & & & 2-Parameter Lognormal & 0.042 & 0.423 \\
\hline $\mathrm{TKN}(\mathrm{mg} / \mathrm{L})$ & 449 & 97.3 & 0.471 & 0.828 & 3-Maximum Likelihood & 0.050 & 0.228 \\
\hline & & & & & 3-Lmoments & 0.032 & 0.816 \\
\hline Dissolved & & & & & 2-Parameter Lognormal & 0.075 & 0.104 \\
\hline Phosphorus & 323 & 81.1 & -2.077 & 1.016 & 3-Maximum Likelihood & 0.062 & 0.273 \\
\hline$(\mathrm{mg} / \mathrm{L})$ & & & & & 3-Lmoments & 0.059 & 0.315 \\
\hline & & & & & 2-Parameter Lognormal & 0.038 & 0.582 \\
\hline 1otal Pnospnorus & 446 & 95.7 & -1.473 & 0.881 & 3-Maximum Likelihood & 0.041 & 0.466 \\
\hline & & & & & 3-Lmoments & 0.049 & 0.264 \\
\hline & & & & & 2-Parameter Lognormal & 0.164 & 0.046 \\
\hline Arsenic $(\mu \mathrm{g} / \mathrm{L})$ & 213 & 32.9 & 0.934 & 0.924 & 3-Maximum Likelihood & 0.195 & 0.010 \\
\hline & & & & & 3-Lmoments & 0.280 & 0.000 \\
\hline Total Cadmium & 358 & 43 & 0.047 & 1.309 & 2-Parameter Lognormal & 0.113 & 0.039 \\
\hline & & & & & 3-Maximum Likelihood & 0.109 & 0.052 \\
\hline
\end{tabular}




\begin{tabular}{|c|c|c|c|c|c|c|c|}
\hline$(\mu \mathrm{g} / \mathrm{L})$ & & & & & 3-Lmoments & 0.063 & 0.591 \\
\hline \multirow{3}{*}{$\begin{array}{l}\text { Total Chromium } \\
\qquad(\mu \mathrm{g} / \mathrm{L})\end{array}$} & \multirow{3}{*}{235} & \multirow{3}{*}{58.7} & \multirow{3}{*}{1.813} & \multirow{3}{*}{0.716} & 2-Parameter Lognormal & 0.086 & 0.262 \\
\hline & & & & & 3-Maximum Likelihood & 0.089 & 0.225 \\
\hline & & & & & 3-Lmoments & 0.083 & 0.295 \\
\hline \multirow{3}{*}{$\begin{array}{c}\text { Total Copper } \\
(\mu \mathrm{g} / \mathrm{L})\end{array}$} & \multirow{3}{*}{387} & \multirow{3}{*}{92.8} & \multirow{3}{*}{2.883} & \multirow{3}{*}{0.901} & 2-Parameter Lognormal & 0.070 & 0.060 \\
\hline & & & & & 3-Maximum Likelihood & 0.063 & 0.117 \\
\hline & & & & & 3-Lmoments & 0.069 & 0.067 \\
\hline \multirow{2}{*}{$\begin{array}{l}\text { Total Lead } \\
(\mu \mathrm{g} / \mathrm{L})\end{array}$} & \multirow[b]{2}{*}{377} & \multirow[b]{2}{*}{85.4} & \multirow[b]{2}{*}{3.033} & \multirow[b]{2}{*}{1.032} & 2-Parameter Lognormal & 0.057 & 0.250 \\
\hline & & & & & 3-Maximum Likelihood & $\begin{array}{l}0.058 \\
0.053\end{array}$ & $\begin{array}{l}0.225 \\
0.329\end{array}$ \\
\hline \multirow{3}{*}{$\begin{array}{l}\text { Total Nickel } \\
(\mu \mathrm{g} / \mathrm{L})\end{array}$} & \multirow{3}{*}{232} & \multirow{3}{*}{59.5} & \multirow{3}{*}{1.978} & \multirow{3}{*}{0.808} & 2-Parameter Lognormal & 0.056 & 0.831 \\
\hline & & & & & 3-Maximum Likelihood & 0.089 & 0.220 \\
\hline & & & & & 3-Lmoments & 0.076 & 0.406 \\
\hline \multirow{3}{*}{$\begin{array}{l}\text { Total Selenium } \\
(\mu \mathrm{g} / \mathrm{L})\end{array}$} & \multirow{3}{*}{169} & \multirow{3}{*}{7.7} & \multirow{3}{*}{1.366} & \multirow{3}{*}{0.953} & 2-Parameter Lognormal & 0.196 & 0.735 \\
\hline & & & & & 3-Maximum Likelihood & 0.167 & 0.670 \\
\hline & & & & & 3-Lmoments & 0.210 & 0.638 \\
\hline \multirow{4}{*}{$\begin{array}{l}\text { Total Silver } \\
(\mu \mathrm{g} / \mathrm{L})\end{array}$} & \multirow{4}{*}{222} & \multirow{4}{*}{11.3} & \multirow{3}{*}{0.964} & \multirow{3}{*}{1.351} & 2-Parameter Lognormal & 0.184 & 0.370 \\
\hline & & & & & 3-Maximum Likelihood & 0.182 & 0.379 \\
\hline & & & & & 3-Lmoments & 0.165 & 0.513 \\
\hline & & & \multirow{3}{*}{5.039} & \multirow{3}{*}{0.842} & 2-Parameter Lognormal & 0.040 & 0.585 \\
\hline \multirow[t]{2}{*}{ Total Zinc $(\mu \mathrm{g} / \mathrm{L})$} & \multirow[t]{2}{*}{392} & \multirow[t]{2}{*}{99} & & & 3-Maximum Likelihood & 0.039 & 0.619 \\
\hline & & & & & 3-Lmoments & 0.052 & 0.243 \\
\hline
\end{tabular}

* P-values greater than 1 used only for comparison. $\mathrm{N}$ : \# collected samples. \%Det: \% detected

Table 13.3 continued Goodness of fit for different land uses.

\begin{tabular}{|c|c|c|c|c|c|c|c|}
\hline \multirow[t]{2}{*}{ CONSTITUENT } & \multirow[t]{2}{*}{$\mathrm{N}$} & \multirow[t]{2}{*}{$\begin{array}{c}\% \\
\text { Det }\end{array}$} & \multicolumn{2}{|c|}{$\begin{array}{c}\text { Sample } \\
\text { Parameters }\end{array}$} & \multirow[t]{2}{*}{ PDF } & \multicolumn{2}{|c|}{ INDUSTRIAL } \\
\hline & & & Mean & $\mathrm{S}$ & & Dmax & P-Value \\
\hline \multirow{3}{*}{$\begin{array}{l}\text { Conductivity } \\
(\mu \mathrm{S} / \mathrm{cm})\end{array}$} & \multirow{3}{*}{108} & \multirow{3}{*}{100} & \multirow{3}{*}{5.011} & \multirow{3}{*}{0.673} & 2-Parameter Lognormal & 0.074 & 0.619 \\
\hline & & & & & $\begin{array}{l}\text { 3-Maximum Likelihood } \\
\text { 3-Lmoments }\end{array}$ & $\begin{array}{l}0.067 \\
0.106\end{array}$ & $\begin{array}{l}0.767 \\
0.174\end{array}$ \\
\hline & & & & & 2-Parameter Lognormal & 0.080 & 0.369 \\
\hline \multirow[t]{3}{*}{ Hardness (mg/L) } & \multirow[t]{3}{*}{138} & \multirow[t]{3}{*}{96.4} & \multirow[t]{3}{*}{3.794} & \multirow[t]{2}{*}{0.842} & 3-Maximum Likelihood & 0.081 & 0.346 \\
\hline & & & & & 3-Lmoments & 0.119 & 0.047 \\
\hline & & & & \multirow{4}{*}{1.153} & 2-Parameter Lognormal & 0.098 & 0.032 \\
\hline \multirow{3}{*}{$\begin{array}{l}\text { Oil \& Grease } \\
\quad(\mathrm{mg} / \mathrm{L})\end{array}$} & \multirow[t]{3}{*}{327} & \multirow[t]{3}{*}{65.1} & \multirow[t]{3}{*}{1.623} & & 3-Maximum Likelihood & 0.093 & 0.048 \\
\hline & & & & & 3-Lmoments & 0.313 & 0.000 \\
\hline & & & & & 2-Parameter Lognormal & 0.066 & 0.053 \\
\hline \multirow[t]{3}{*}{ TDS (mg/L) } & \multirow[t]{3}{*}{413} & \multirow[t]{3}{*}{99.5} & \multirow[t]{3}{*}{4.516} & \multirow[t]{3}{*}{0.870} & 3-Maximum Likelihood & 0.065 & 0.064 \\
\hline & & & & & 3-Lmoments & 0.111 & 0.000 \\
\hline & & & & & 2-Parameter Lognormal & 0.029 & 0.995 \\
\hline \multirow[t]{3}{*}{$\mathrm{TSS}(\mathrm{mg} / \mathrm{L})$} & \multirow[t]{3}{*}{428} & \multirow[t]{3}{*}{99.1} & \multirow[t]{3}{*}{4.287} & \multirow[t]{3}{*}{1.200} & 3-Maximum Likelihood & 0.028 & 1.023 \\
\hline & & & & & 3-Lmoments & 0.026 & 1.119 \\
\hline & & & & & 2-Parameter Lognormal & 0.105 & 0.000 \\
\hline \multirow[t]{3}{*}{$\mathrm{BOD}(\mathrm{mg} / \mathrm{L})$} & \multirow[t]{3}{*}{406} & 95.3 & 2.412 & 0.992 & 3-Maximum Likelihood & 0.095 & 0.002 \\
\hline & & & & & 3-Lmoments & 0.184 & 0.000 \\
\hline & & & & & 2-Parameter Lognormal & 0.074 & 0.040 \\
\hline $\mathrm{COD}(\mathrm{mg} / \mathrm{L})$ & 362 & 98.9 & 4.222 & 0.914 & 3-Maximum Likelihood & 0.076 & 0.032 \\
\hline & & & & & 3-Lmoments & 0.046 & 0.437 \\
\hline & & & & & 2-Parameter Lognormal & 0.051 & 0.510 \\
\hline (Col/100 ml & 297 & 87.9 & 7.606 & 2.660 & 3-Maximum Likelihood & 0.055 & 0.417 \\
\hline & & & & & 3-Lmoments & 0.045 & 0.688 \\
\hline
\end{tabular}




\begin{tabular}{|c|c|c|c|c|c|c|c|}
\hline Fecal & \multirow{4}{*}{195} & \multirow{3}{*}{93.8} & \multirow{3}{*}{9.149} & \multirow{3}{*}{1.829} & 2-Parameter Lognormal & 0.083 & 0.161 \\
\hline \multirow{3}{*}{$\begin{array}{l}\text { Streptococcus } \\
(\mathrm{C} / 100 \mathrm{ml})\end{array}$} & & & & & 3-Maximum Likelihood & 0.073 & 0.280 \\
\hline & & & & & 3-Lmoments & 0.199 & 0.000 \\
\hline & & \multirow{4}{*}{85.8} & \multirow{4}{*}{-0.707} & \multirow{4}{*}{1.009} & 2-Parameter Lognormal & 0.047 & 0.758 \\
\hline \multirow[t]{3}{*}{ Ammonia (mg/L) } & \multirow[t]{3}{*}{254} & & & & 3-Maximum Likelihood & 0.049 & 0.715 \\
\hline & & & & & 3-Lmoments & 0.046 & 0.789 \\
\hline & & & & & 2-Parameter Lognormal & 0.080 & 0.011 \\
\hline \multirow[t]{3}{*}{$\mathrm{NO} 2+\mathrm{NO} 3(\mathrm{mg} / \mathrm{L})$} & \multirow[t]{3}{*}{418} & \multirow[t]{3}{*}{96.2} & \multirow[t]{3}{*}{-0.386} & \multirow[t]{3}{*}{0.931} & 3-Maximum Likelihood & 0.043 & 0.454 \\
\hline & & & & & 3-Lmoments & 0.045 & 0.406 \\
\hline & & & & & 2-Parameter Lognormal & 0.048 & 0.292 \\
\hline \multirow[t]{2}{*}{ TKN (mg/L) } & \multirow[t]{2}{*}{440} & \multirow[t]{2}{*}{95.9} & \multirow[t]{2}{*}{0.424} & \multirow[t]{2}{*}{0.884} & 3-Maximum Likelihood & 0.050 & 0.239 \\
\hline & & & & & 3-Lmoments & 0.040 & 0.502 \\
\hline Dissolved & & & & & 2-Parameter Lognormal & 0.124 & 0.682 \\
\hline Phosphorus & 325 & 87.1 & -2.177 & 0.871 & 3-Maximum Likelihood & 0.051 & 0.450 \\
\hline$(\mathrm{mg} / \mathrm{L})$ & & & & & 3-Lmoments & 0.063 & 0.211 \\
\hline Total Phosnhorus & & & & & 2-Parameter Lognormal & 0.049 & 0.273 \\
\hline$(\mathrm{mg} / \mathrm{L})$ & 434 & 96.3 & -1.268 & 0.982 & 3-Maximum Likelihood & 0.044 & 0.387 \\
\hline & & & & & 3-Lmoments & 0.035 & 0.724 \\
\hline & & & & & 2-Parameter Lognormal & 0.096 & 1.279 \\
\hline Antimony $(\mu \mathrm{g} / \mathrm{L})$ & 164 & 14.6 & 1.479 & 1.013 & 3-Maximum Likelihood & 0.113 & 1.088 \\
\hline & & & & & 3-Lmoments & 0.150 & 0.684 \\
\hline & & & & & 2-Parameter Lognormal & 0.129 & 0.016 \\
\hline Arsenic $(\mu \mathrm{g} / \mathrm{L})$ & 267 & 54.3 & 1.522 & 0.952 & 3-Maximum Likelihood & 0.128 & 0.018 \\
\hline & & & & & 3-Lmoments & 0.116 & 0.039 \\
\hline & & & & & 2-Parameter Lognormal & 0.163 & 0.620 \\
\hline Beryllium $(\mu \mathrm{g} / \mathrm{L})$ & 209 & 10.5 & -0.359 & 1.948 & 3-Maximum Likelihood & 0.197 & 0.362 \\
\hline & & & & & 3-Lmoments & 0.231 & 0.191 \\
\hline & & & & & 2-Parameter Lognormal & 0.083 & 0.136 \\
\hline 1 otal cadmium & 395 & 49.4 & 0.742 & 1.126 & 3-Maximum Likelihood & 0.095 & 0.060 \\
\hline & & & & & 3-Lmoments & 0.115 & 0.012 \\
\hline Total Chromium & & & & & 2-Parameter Lognormal & 0.062 & 0.480 \\
\hline$(\mu \mathrm{g} / \mathrm{L})$ & 256 & 72.7 & 2.551 & 1.069 & 3-Maximum Likelihood & 0.059 & 0.543 \\
\hline & & & & & 3-Lmoments & 0.050 & 0.803 \\
\hline Total Conner & & & & & 2-Parameter Lognormal & 0.080 & 0.017 \\
\hline$(\mu \mathrm{g} / \mathrm{L})$ & 416 & 89.9 & 3.228 & 1.029 & 3-Maximum Likelihood & 0.073 & 0.030 \\
\hline & & & & & 3-Lmoments & 0.057 & 0.172 \\
\hline & & & & & 2-Parameter Lognormal & 0.059 & 0.223 \\
\hline Total Lead $(\mu \mathrm{g} / \mathrm{L})$ & 412 & 76.5 & 3.365 & 1.328 & 3-Maximum Likelihood & 0.057 & 0.263 \\
\hline & & & & & 3-Lmoments & 0.054 & 0.316 \\
\hline & & & & & 2-Parameter Lognormal & 0.065 & 0.525 \\
\hline I otal Nickel & 250 & 62.4 & 2.806 & 0.970 & 3-Maximum Likelihood & 0.066 & 0.512 \\
\hline & & & & & 3-Lmoments & 0.088 & 0.182 \\
\hline & & & & & 2-Parameter Lognormal & 0.190 & 0.841 \\
\hline rotal serenium & 203 & 5.9 & 1.147 & 1.277 & 3-Maximum Likelihood & 0.364 & 0.083 \\
\hline & & & & & 3-Lmoments & 0.202 & 0.753 \\
\hline & & & & & 2-Parameter Lognormal & 0.146 & 0.236 \\
\hline 1 otal Silver & 287 & 17.4 & 0.113 & 1.808 & 3-Maximum Likelihood & 0.153 & 0.194 \\
\hline & & & & & 3-Lmoments & 0.157 & 0.170 \\
\hline & & & & & 2-Parameter Lognormal & 0.044 & 0.389 \\
\hline Total Zinc $(\mu \mathrm{g} / \mathrm{L})$ & 433 & 98.6 & 5.305 & 0.970 & 3-Maximum Likelihood & 0.034 & 0.743 \\
\hline & & & & & 3-Lmoments & 0.030 & 0.951 \\
\hline
\end{tabular}


Table 13.3 continued Goodness of fit for different land uses.

\begin{tabular}{|c|c|c|c|c|c|c|c|}
\hline \multirow[t]{2}{*}{ CONSTITUENT } & \multirow[t]{2}{*}{$\mathrm{N}$} & \multirow[t]{2}{*}{$\begin{array}{c}\% \\
\text { Det }\end{array}$} & \multicolumn{2}{|c|}{$\begin{array}{c}\text { Sample } \\
\text { Parameters } \\
\text { (Log Scale) }\end{array}$} & \multirow[t]{2}{*}{ PDF } & \multicolumn{2}{|c|}{ OPEN SPACE } \\
\hline & & & Mean & $\mathrm{S}$ & & Dmax & P-Value \\
\hline \multirow[t]{3}{*}{ TDS (mg/L) } & \multirow[t]{3}{*}{45} & \multirow[t]{3}{*}{97.8} & \multirow[t]{3}{*}{4.762} & \multirow[t]{3}{*}{0.744} & 2-Parameter Lognormal & 0.120 & 0.561 \\
\hline & & & & & 3-Maximum Likelihood & 0.115 & 0.621 \\
\hline & & & & & 3-Lmoments & 0.759 & 0.000 \\
\hline \multirow[t]{3}{*}{ TSS (mg/L) } & \multirow[t]{3}{*}{44} & \multirow[t]{3}{*}{95.5} & \multirow[t]{3}{*}{3.945} & \multirow[t]{3}{*}{1.717} & 2-Parameter Lognormal & 0.113 & 0.683 \\
\hline & & & & & 3-Maximum Likelihood & 0.095 & 0.942 \\
\hline & & & & & 3-Lmoments & 0.173 & 0.162 \\
\hline \multirow[t]{3}{*}{$\mathrm{BOD}(\mathrm{mg} / \mathrm{L})$} & \multirow[t]{3}{*}{44} & \multirow[t]{3}{*}{86.4} & \multirow[t]{3}{*}{1.621} & \multirow[t]{3}{*}{0.670} & 2-Parameter Lognormal & 0.114 & 0.746 \\
\hline & & & & & 3-Maximum Likelihood & 0.115 & 0.733 \\
\hline & & & & & 3-Lmoments & 0.110 & 0.801 \\
\hline \multirow[t]{3}{*}{$\mathrm{COD}(\mathrm{mg} / \mathrm{L})$} & 43 & 76.7 & 3.548 & 0.785 & 2-Parameter Lognormal & 0.128 & 0.684 \\
\hline & & & & & 3-Maximum Likelihood & 0.151 & 0.441 \\
\hline & & & & & 3-Lmoments & 0.184 & 0.215 \\
\hline Fecal Coliform & 23 & 91.3 & 8.953 & 1.432 & 2-Parameter Lognormal & 0.181 & 0.503 \\
\hline$(\mathrm{Col} / 100 \mathrm{ml})$ & & & & & 3-Maximum Likelihood & 0.217 & 0.278 \\
\hline & & & & & 3-Lmoments & 0.187 & 0.458 \\
\hline Fecal & 22 & 90.9 & 9.647 & 1.628 & 2-Parameter Lognormal & 0.181 & 0.538 \\
\hline Streptococcus & & & & & 3-Maximum Likelihood & 0.165 & 0.676 \\
\hline$(\mathrm{C} / 100 \mathrm{ml})$ & & & & & 3-Lmoments & 0.139 & 0.921 \\
\hline $\mathrm{NO} 2+\mathrm{NO} 3$ & 44 & 84.1 & -0.478 & 1.074 & 2-Parameter Lognormal & 0.141 & 0.463 \\
\hline$(\mathrm{mg} / \mathrm{L})$ & & & & & 3-Maximum Likelihood & 0.141 & 0.464 \\
\hline & & & & & 3-Lmoments & 0.122 & 0.664 \\
\hline $\mathrm{TKN}(\mathrm{mg} / \mathrm{L})$ & 45 & 71.1 & -0.097 & 0.925 & 2-Parameter Lognormal & 0.147 & 0.500 \\
\hline & & & & & 3-Maximum Likelihood & 0.140 & 0.569 \\
\hline & & & & & 3-Lmoments & 0.160 & 0.389 \\
\hline Dissolved & 44 & 79.5 & -2.184 & 1.084 & 2-Parameter Lognormal & 0.124 & 0.682 \\
\hline Phosphorus & & & & & 3-Maximum Likelihood & 0.131 & 0.606 \\
\hline$(\mathrm{mg} / \mathrm{L})$ & & & & & 3-Lmoments & 0.142 & 0.484 \\
\hline Total Phosphorus & 46 & 84.8 & -1.426 & 1.126 & 2-Parameter Lognormal & 0.116 & 0.696 \\
\hline (mg/L) & & & & & 3-Maximum Likelihood & 0.126 & 0.584 \\
\hline & & & & & 3-Lmoments & 0.211 & 0.062 \\
\hline Total Cadmium & 38 & 55.3 & 0.029 & 2.623 & 2-Parameter Lognormal & 0.206 & 0.338 \\
\hline$(\mu \mathrm{g} / \mathrm{L})$ & & & & & 3-Maximum Likelihood & 0.327 & 0.022 \\
\hline & & & & & 3-Lmoments & 0.319 & 0.028 \\
\hline Total Chromium & 36 & 36.1 & -1.790 & 1.662 & 2-Parameter Lognormal & 0.799 & 0.000 \\
\hline$(\mu \mathrm{g} / \mathrm{L})$ & & & & & 3-Maximum Likelihood & 0.275 & 0.279 \\
\hline & & & & & 3-Lmoments & 0.193 & 0.756 \\
\hline Total Copper & 39 & 74.4 & 2.118 & 1.200 & 2-Parameter Lognormal & 0.131 & 0.742 \\
\hline$(\mu \mathrm{g} / \mathrm{L})$ & & & & & 3-Maximum Likelihood & 0.334 & 0.003 \\
\hline & & & & & 3-Lmoments & 0.187 & 0.262 \\
\hline Total Lead & 45 & 42.2 & 1.888 & 1.954 & 2-Parameter Lognormal & 0.132 & 1.034 \\
\hline$(\mu \mathrm{g} / \mathrm{L})$ & & & & & 3-Maximum Likelihood & 0.203 & 0.417 \\
\hline & & & & & 3-Lmoments & 0.174 & 0.632 \\
\hline Total Zinc $(\mu \mathrm{g} / \mathrm{L})$ & 45 & 71.1 & 3.605 & 1.198 & 2-Parameter Lognormal & 0.105 & 0.981 \\
\hline & & & & & 3-Maximum Likelihood & 0.132 & 0.658 \\
\hline & & & & & 3-Lmoments & 0.113 & 0.885 \\
\hline
\end{tabular}


Table 13.3 continued Goodness of fit for different land uses.

\begin{tabular}{|c|c|c|c|c|c|c|c|}
\hline \multirow[t]{2}{*}{ CONSTITUENT } & \multirow[t]{2}{*}{$\mathrm{N}$} & \multirow[t]{2}{*}{$\begin{array}{l}\% \\
\text { Det }\end{array}$} & \multicolumn{2}{|c|}{$\begin{array}{c}\text { Sample } \\
\text { Parameters } \\
\text { (Log Scale) }\end{array}$} & \multirow[t]{2}{*}{ PDF } & \multicolumn{2}{|c|}{ FREEWAYS } \\
\hline & & & Mean & $\mathrm{S}$ & & Dmax & P-Value \\
\hline \multirow{3}{*}{$\begin{array}{l}\text { Conductivity } \\
(\mu \mathrm{S} / \mathrm{cm})\end{array}$} & \multirow[t]{3}{*}{86} & \multirow[t]{3}{*}{100} & \multirow[t]{3}{*}{4.586} & \multirow[t]{3}{*}{0.681} & 2-Parameter Lognormal & 0.129 & 0.113 \\
\hline & & & & & 3-Maximum Likelihood & 0.113 & 0.226 \\
\hline & & & & & 3-Lmoments & 0.096 & 0.411 \\
\hline \multirow[t]{3}{*}{ Hardness $(\mathrm{mg} / \mathrm{L})$} & \multirow[t]{3}{*}{127} & \multirow[t]{3}{*}{100} & \multirow[t]{3}{*}{3.604} & \multirow[t]{3}{*}{0.791} & 2-Parameter Lognormal & 0.077 & 0.447 \\
\hline & & & & & 3-Maximum Likelihood & 0.077 & 0.440 \\
\hline & & & & & 3-Lmoments & 0.114 & 0.074 \\
\hline \multirow{3}{*}{$\begin{array}{l}\text { Oil \& Grease } \\
(\mathrm{mg} / \mathrm{L})\end{array}$} & \multirow[t]{3}{*}{60} & \multirow[t]{3}{*}{71.7} & \multirow[t]{3}{*}{1.974} & \multirow[t]{3}{*}{0.575} & 2-Parameter Lognormal & 0.101 & 0.827 \\
\hline & & & & & 3-Maximum Likelihood & 0.161 & 0.214 \\
\hline & & & & & 3-Lmoments & 0.098 & 0.881 \\
\hline TDS (mg/L) & 97 & 99 & 4.279 & 0.771 & 2-Parameter Lognormal & 0.054 & 1.136 \\
\hline & & & & & 3-Maximum Likelihood & 0.051 & 1.210 \\
\hline & & & & & 3-Lmoments & 0.044 & 1.368 \\
\hline $\mathrm{TSS}(\mathrm{mg} / \mathrm{L})$ & 134 & 99.3 & 4.464 & 1.068 & 2-Parameter Lognormal & 0.066 & 0.627 \\
\hline & & & & & 3-Maximum Likelihood & 0.059 & 0.797 \\
\hline & & & & & 3-Lmoments & 0.120 & 0.043 \\
\hline $\mathrm{BOD}(\mathrm{mg} / \mathrm{L})$ & 26 & 84.6 & 2.262 & 0.894 & 2-Parameter Lognormal & 0.103 & 1.252 \\
\hline & & & & & 3-Maximum Likelihood & 0.099 & 1.304 \\
\hline & & & & & 3-Lmoments & 0.117 & 1.097 \\
\hline $\mathrm{COD}(\mathrm{mg} / \mathrm{L})$ & 67 & 98.5 & 4.552 & 0.980 & 2-Parameter Lognormal & 0.107 & 0.445 \\
\hline & & & & & 3-Maximum Likelihood & 0.073 & 0.999 \\
\hline & & & & & 3-Lmoments & 0.082 & 0.817 \\
\hline Fecal Coliform & 49 & 100 & 7.585 & 1.716 & 2-Parameter Lognormal & 0.105 & 0.677 \\
\hline$(\mathrm{Col} / 100 \mathrm{ml})$ & & & & & 3-Maximum Likelihood & 0.128 & 0.398 \\
\hline & & & & & 3-Lmoments & 0.108 & 0.635 \\
\hline Fecal & 25 & 100 & 9.263 & 1.662 & 2-Parameter Lognormal & 0.119 & 0.990 \\
\hline Streptococcus & & & & & 3-Maximum Likelihood & 0.211 & 0.215 \\
\hline$(\mathrm{C} / 100 \mathrm{ml})$ & & & & & 3-Lmoments & 0.132 & 0.833 \\
\hline Ammonia $(\mathrm{mg} / \mathrm{L})$ & 79 & 87.3 & 0.009 & 1.094 & 2-Parameter Lognormal & 0.133 & 0.173 \\
\hline & & & & & 3-Maximum Likelihood & 0.106 & 0.423 \\
\hline & & & & & 3-Lmoments & 0.123 & 0.252 \\
\hline $\mathrm{NO} 2+\mathrm{NO} 3$ & 25 & 96 & -1.097 & 0.868 & 2-Parameter Lognormal & 0.139 & 0.789 \\
\hline$(\mathrm{mg} / \mathrm{L})$ & & & & & 3-Maximum Likelihood & 0.114 & 1.073 \\
\hline & & & & & 3-Lmoments & 0.117 & 1.038 \\
\hline TKN (mg/L) & 125 & 96.8 & 0.750 & 0.887 & 2-Parameter Lognormal & 0.074 & 0.539 \\
\hline & & & & & 3-Maximum Likelihood & 0.075 & 0.512 \\
\hline & & & & & 3-Lmoments & 0.071 & 0.598 \\
\hline Dissolved & 22 & 95.5 & -1.226 & 1.188 & 2-Parameter Lognormal & 0.170 & 0.593 \\
\hline Phosphorus & & & & & 3-Maximum Likelihood & 0.207 & 0.333 \\
\hline$(\mathrm{mg} / \mathrm{L})$ & & & & & 3-Lmoments & 0.255 & 0.131 \\
\hline & 128 & 99.2 & -1.266 & 0.772 & 2-Parameter Lognormal & 0.085 & 0.325 \\
\hline $\begin{array}{l}\text { 1otal Phosphorus } \\
(\mathrm{mg} / \mathrm{L})\end{array}$ & & & & & 3-Maximum Likelihood & 0.065 & 0.686 \\
\hline & & & & & 3-Lmoments & 0.089 & 0.27 \\
\hline Antimony $(\mu \mathrm{g} / \mathrm{L})$ & 14 & 50 & 0.967 & 0.284 & 2-Parameter Lognormal & 0.419 & 0.171 \\
\hline & & & & & 3-Maximum Likelihood & 0.397 & 0.220 \\
\hline & & & & & 3-Lmoments & 0.270 & 0.719 \\
\hline Arsenic $(\mu \mathrm{g} / \mathrm{L})$ & 61 & 55.7 & 0.952 & 0.666 & 2-Parameter Lognormal & 0.149 & 0.441 \\
\hline
\end{tabular}




\begin{tabular}{|c|c|c|c|c|c|c|c|}
\hline & & & & & 3-Maximum Likelihood & 0.106 & 0.937 \\
\hline & & & & & 3-Lmoments & 0.096 & 1.070 \\
\hline \multirow{3}{*}{$\begin{array}{l}\text { Total Cadmium } \\
(\mu \mathrm{g} / \mathrm{L})\end{array}$} & \multirow[t]{3}{*}{95} & \multirow[t]{3}{*}{71.6} & \multirow[t]{3}{*}{0.016} & \multirow[t]{3}{*}{0.838} & 2-Parameter Lognormal & 0.052 & 1.380 \\
\hline & & & & & 3-Maximum Likelihood & 0.067 & 1.087 \\
\hline & & & & & 3-Lmoments & 0.051 & 1.409 \\
\hline \multirow{3}{*}{$\begin{array}{l}\text { Total Chromium } \\
(\mu \mathrm{g} / \mathrm{L})\end{array}$} & \multirow[t]{3}{*}{76} & \multirow[t]{3}{*}{98.7} & \multirow[t]{3}{*}{2.096} & \multirow[t]{3}{*}{0.734} & 2-Parameter Lognormal & 0.084 & 0.685 \\
\hline & & & & & 3-Maximum Likelihood & 0.075 & 0.854 \\
\hline & & & & & 3-Lmoments & 0.055 & 1.272 \\
\hline \multirow{3}{*}{$\begin{array}{l}\text { Total Copper } \\
(\mu \mathrm{g} / \mathrm{L})\end{array}$} & \multirow[t]{3}{*}{97} & \multirow[t]{3}{*}{99.0} & \multirow[t]{3}{*}{3.525} & \multirow[t]{3}{*}{0.842} & 2-Parameter Lognormal & 0.038 & 1.507 \\
\hline & & & & & 3-Maximum Likelihood & 0.048 & 1.295 \\
\hline & & & & & 3-Lmoments & 0.041 & 1.443 \\
\hline \multirow{3}{*}{$\begin{array}{l}\text { Total Lead } \\
(\mu \mathrm{g} / \mathrm{L})\end{array}$} & \multirow[t]{3}{*}{107} & \multirow[t]{3}{*}{100} & \multirow[t]{3}{*}{3.226} & \multirow[t]{3}{*}{1.164} & 2-Parameter Lognormal & 0.039 & 1.451 \\
\hline & & & & & 3-Maximum Likelihood & 0.045 & 1.285 \\
\hline & & & & & 3-Lmoments & 0.040 & 1.424 \\
\hline \multirow{3}{*}{$\begin{array}{l}\text { Total Nickel } \\
(\mu \mathrm{g} / \mathrm{L})\end{array}$} & \multirow[t]{3}{*}{99} & \multirow[t]{3}{*}{89.9} & \multirow[t]{3}{*}{2.325} & \multirow[t]{3}{*}{0.673} & 2-Parameter Lognormal & 0.091 & 0.460 \\
\hline & & & & & 3-Maximum Likelihood & 0.062 & 1.013 \\
\hline & & & & & 3-Lmoments & 0.073 & 0.769 \\
\hline \multirow[t]{3}{*}{ Total Zinc $(\mu \mathrm{g} / \mathrm{L})$} & \multirow[t]{3}{*}{93} & \multirow[t]{3}{*}{96.8} & \multirow[t]{3}{*}{5.273} & \multirow[t]{3}{*}{0.877} & 2-Parameter Lognormal & 0.063 & 0.985 \\
\hline & & & & & 3-Maximum Likelihood & 0.054 & 1.000 \\
\hline & & & & & 3-Lmoments & 0.064 & 0.959 \\
\hline
\end{tabular}

* P-values greater than one are used only for comparison. $\mathrm{N}$ : Number of collected samples. \%Det. percentage detected

\subsection{Discussion}

Most of the stormwater constituents can be assumed to follow a lognormal distribution with little error. The use of the third parameter does not show a significant improvement in estimating the empirical distribution compared with the two parameter lognormal. When the number of samples is large per category (approximately more than 400 samples) the maximum likelihood and the two parameter lognormal distribution better fit the empirical distribution. For large sample sizes, the L-moments method usually unacceptably truncates the distribution in the lower tail. When the sample size is small $(<100$ samples), the use of the third parameter does not improve the fit with the empirical distribution and the two parameter lognormal distribution produces a better fit than the other two methods.

The lognormal distribution is a skewed distribution. When the sample size is small the calculated skewness is smaller than the skewness of the real distribution. The power of the Kolmogorov-Smirnov test is small when the number of samples is small. It is possible in some cases that without being able to identify the real skewness, the best fit could be assigned to the gamma or exponential distributions. 
The utility of the third parameter has been questioned, especially because one of the objectives in modeling is parsimonious. Only in cases where it is important to include in the model the effect of unusual elevated values, the third parameter is suggested; in all the other cases the use of the twoparameter is adequate to explain the distribution of most of the contaminants.

When the mean and the standard deviation are not known Lilieford's test is recommended to evaluate the goodness of fit. In this case the KolmogorovSmirnov test was used based in the assumption that with a large sample size the test will be not affected.

Some constituents (such as TKN, TP, COD and $\mathrm{Cu}$ ) show an increase in the $p$-value when the number of samples is acceptable and the 3-parameter lognormal probability distribution is used. The use of the lognormal distribution also has an advantage over the other distributions because it can be easily transformed to a normal distribution.

The few cases where gamma distribution seems to be a better model was for cases with low counts (open space constituents, arsenic, chromium and fecal streptococcus in freeways areas for example). The exponential distribution better fit total ammonia in freeway areas. The remaining constituents were well represented by the lognormal distribution.

Future studies will involve the use of non-detected observations and the development of multivariate and general linear models to estimate stormwater concentrations for different seasons, geographic location, level of impervious and precipitation depth. Some of the requirements of these models are that the residuals have the same variance and that they are normally distributed. The

use of lognormal transformations will facilitate the development of the predictive models.

\section{References}

Behera, P., J. Li and B.J. Adams. 2000. "Characterization of Urban Runoff Quality: A Toronto Case Study." Journal of Water Management Modeling R206-14. doi: 10.14796/JWMM.R206-14.

Gibbons, J. Chakraborti, S. Nonparametric Statistical Inference. Marcel Dekker Inc. New York, NY. Fourth Edition (2003) 645 pages.

Kottegoda N.T. and Rosso R. Statistics, Probability and Reliability for Civil and Environmental Engineers. WCB McGraw-Hill. New York, NY. 1998

Massey , F. J. Jr. "A Note on the Power of a Non-Parametric Test”. Annals of Mathematical Statistics, 21 (1950) 440-443

Massey , F. J. Jr. "The Kolmogorov-Smirnov Test for Goodness of Fit." Journal of the American Statistical Association, 46, No 253 (1951) 67-78 
Pitt, R. "The Incorporation of Urban Runoff Controls in the Wisconsin Priority Watershed Program." In: Advanced Topics in Urban Runoff Research, (Edited by B. Urbonas and L.A. Roesner). Engineering Foundation and ASCE, New York. pp. 290-313. 1986.

Pitt, R. and J. Voorhees. "Source loading and management model (SLAMM)." Seminar Publication: National Conference on Urban Runoff Management: Enhancing Urban Watershed Management at the Local, County, and State Levels. March 30 - April 2, 1993. Center for Environmental Research Information, U.S. Environmental Protection Agency. EPA/625/R-95/003. Cincinnati. Ohio. pp. 225-243. April 1995.

Pitt, R. Maestre A. Morquecho R. "Evaluation of NPDES Phase I Municipal Stormwater Monitoring Data" in: National Conference on Urban Stormwater: Enhancing the Programs at the Local Level. EPA/625/R-03/003. February 2003.

U.S. Environmental Protection Agency. Results of the Nationwide Urban Runoff Program. Water Planning Division, PB 84-185552, Washington, D.C. 1983

Van Buren M. A. Watt, W. E. Marsalek J. "Application of the Log-normal and Normal Distributions to Stormwater Quality Parameters". Water Research Vol. 31 No. 1 pp. 95-104, 1997. 